\title{
Netflix’teki Türk Dizilerinin Sembolik Etkileşimcilik ve Kahramanların Toplumsal Cinsiyet Açısından Ele Alınması: Atiye ve Hakan Muhafız Dizileri Karşılaştırılması
}

\author{
Dilan Çiftçi (Doç. Dr.) \\ Uluslararası Kıbrıs Üniversitesi Iletişim Fakültesi \\ dciftci@ciu.edu.tr \\ Başvuru Tarihi: 16.09 .2020 \\ Yayına Kabul Tarihi: 28.12.2020 \\ Yayınlanma Tarihi: 29.01.2021 \\ https://doi.org/10.17680/erciyesiletisim.795797
}

\section{Öz}

Efsaneler ve mitolojik kahramanlar her dönem ilgi odağı olmayı başarmış hikayeler olarak farklı disiplinlerde çeşitli çalışmalara verimli kaynaklar sunmaktadır. Bu çalışmada sembolik etkileşim alanı olarak kabul edilen televizyon dizilerinden hareketle son dönemlerde popüler olan mitolojik kahraman dizileri toplumsal cinsiyet rolleri açısından karşılaştırmalı olarak ele alınmıştır. Bu bağlamda öncelikle Atiye ve Hakan Muhafız dizilerinin gösterenlerinin üç boyutu, göstergebilimsel açıdan ve söylem analizi olarak ortaya konmuştur. Bunlara ilaveten iki mitolojik kahramanın toplumsal cinsiyet rolleri açısından temsiline yönelik karşılaştırmalı bulgular ortaya konmuştur. İki dizide de olayın merkezini oluşturan mekanlar (Göbeklitepe ve Ayasofya) sembolik açıdan önem taşımaktadır. İki kahraman insan üstü güçlere sahip olmakla birlikte kadın kahraman için bu güçler daha ruhani iken erkek kahraman için bu güç fiziki olmuştur. İki dizide de kahramanlığı sembolize eden nesnelerin varlığı mevcuttur. Kadın kahraman için bu nesne kolye iken erkek kahraman için bu nesne hançer, tılsımlı gömlek ve yüzüktür. Kadın kahramanın olduğu Atiye dizisi antropoloji, astroloji ve arkeoloji gibi farklı disiplinlerden beslenirken, erkek kahramanın olduğu Hakan Muhafız dizisi tarihten beslenmektedir.

Anahtar Kelimeler: İletişim, Mit, Mitolojik Kahraman, İnsanüstü Güçler, Efsanevi Nesneler, Toplumsal Cinsiyet. 


\title{
Symbolic Interaction in Netflix Turkish Series and Handling of Heroes in Terms of Gender: Comparison of Atiye and Hakan Muhafız Series
}

\author{
Dilan Çiftçi (Assoc. Prof. Dr.) \\ Cyprus International University Faculty of Communication \\ dciftci@ciu.edu.tr
}

Date Received: 16.09.2020

Date Accepted: 28.12.2020

Date Published: 29.01.2021

https://doi.org/10.17680/erciyesiletisim.795797

\begin{abstract}
Legends and mythological heroes provide efficient resources for various disciplines. In this study, the mythological hero series, which has been popular recently, based on the television series accepted as a symbolic interaction area, has been compared in terms of gender roles. In this context, the three dimensions of the indicators of the Atiye and Hakan Muhafiz series have been put forward in terms of semiotics. Besides, comparative findings of two mythological heroes' representation in terms of gender roles have been revealed. The spaces (Göbeklitepe and Ayasofya) that form the event are symbolically important for both series. While two heroes have superhuman powers, these powers are more spiritual for the female hero, while the power for the male hero is physical. Some objects symbolize heroism in both series. While this object is a necklace for a female hero, for the male hero is a dagger, talisman shirt, and ring. While Atiye drama is fed by anthropology, astrology, and archeology, the Hakan Muhafiz fed by history.
\end{abstract}

Keywords: Communication, Myth, Mythological Hero, Superhuman Powers, Legendary Objects, Gender. 


\section{Giriş}

Mitler, efsaneler ve halk hikayelerinin, insanların ve toplumların hayatlarını anlamlandırmada önemli rolleri vardır. Batı dünyasında olduğu gibi İslam dünyasında da bu konu ile ilgili önemli literatür kaynaklarına rastlamak mümkündür. Bu çalışma, söz konusu literatür temel alınarak, efsane ve mitlerin işlevleriyle modern toplumda nasıl yer buldukları popüler diziler bazında okumalar yapmayı hedeflemektedir.

Mitler ve efsaneler, ait oldukları toplumların inanç dünyalarını olușturmaya katkı koymaktadırlar. Bu sebeple, toplumların kültürel olduğu kadar milli kodlarının da oluşmasını sağlamaktadırlar. Ait oldukları toplumların kültürünü, ayrıca kimliğini korumada ve toplumsal değerlerin benimsenip uygulanmasında etkili olmaktadırlar. Tarihin ilk devirlerinden başlayarak, günümüz modern yaşantısında da insan, kutsal ve doğa üstü olana yaklaşmaya her zaman ihtiyaç duymuştur. Günümüzde özellikle mitler, radyo, televizyon veya sinemada farklı farklı kılıklarda karşımıza çıkmaktadır. Diğer yandan yine farklı dini veya kültürel içerikli bayramlarda ya da festivallerde kendini göstermektedir.

$\mathrm{Bu}$ çalışmada, öncelikle temel olarak mit kavramı irdelenmiş olup, tarihi akış içinde bu kavram etrafında gelişen tartışmalar incelenmiştir. Diğer anlatı türlerinden farklı olarak, genel anlamıyla toplumsal işlevleri ve onun modern dünyaya nasıl yansıdığı ortaya konulmuştur. Netflix yapımı Atiye ve Hakan Muhafız dizileri ise örnek olay olarak incelenmiştir. Dolayısıyla, bu çalışmanın temel amacı, mitlerin, efsanelerin ayrıca halk hikayelerinin insanların hayatlarını ne șekilde anlamlandırdıkları; popüler diziler aracılığı ile dolaşıma sunulan bu türde yeni mit ve efsanelerin temsili ile diziler üzerinden okunmasıdır. Bu bağlamda söz konusu 2 (iki) dizideki efsaneler benzerlik ve farklılıkların sebepleri üzerinden yürütülen tartışmada ortaya koyulurken söz konusu farklılık ve benzerlikler için toplumsal cinsiyet rolleri, mitler ve efsaneler üzerinden okumalar ortaya koymaktadır.

\section{Kavramsal Çerçeve}

\subsection{Mitin Kökeni ve Tanımları}

André Suarès (1954) her tanımlamanın bir sınırlama getirdiğini ifade etmektedir. Bir kavram tanımlanırken oluşturulmak zorunda bırakılan çerçeveden dolayı genellemeler yapılmakta ve genelde tanımlanmakta olan kavramın işlevlerinden herhangi biri dışarıda bırakılmak zorunda kalınmaktadır. Çünkü (Suarès, 1954), kavramların da insana benzediğini düşünmektedir. Kavramlar da aynı insanlar gibi yaşar, gelişir, değişir ve bu değişimler doğrultusunda yeni şekiller kazanırlar. Bu durumun gerçekleşmesindeki en büyük neden, insan ve kültüre dair kavramların, insanla birlikte aralıksız bir gelişim, ayrıca değişim içinde olmasıdır. Bu yüzden, bu kavramları bir anlığına olsa dahi dondurmanın olanağı yoktur. Oysa bir tanımlama yapıldığında, bir anlamda kavramın içermiş olduğu anlamı dondurmuş olmaktayız. İşte bu durumdan yola çıkarak mit gibi bir kavramı tanımlamak neredeyse imkansızdır. Çünkü mit, her geçen gün boyut olarak yeni bir anlam kazanmaktadır ve kavramın tanımı ne eksik ne de fazla olmaktadır.

Aslında bütün bu tarihin derinliklerine ışık tutan belirsizlikler, mitlerin, insana dair ne kadar çok zenginlik ve sınırsızlık barındırdığını göstermektedir. Bu yüzden Joseph Campbell, Shakspeare'in sanatın işlevini tanımlarken kullandığı "Doğayı olduğu gibi gösterecek aynayı tutmak" sözünün mitolojinin tanımı için de kullanılabileceğini savunmaktadır (Campbell , 1994, s. 14). Ancak bu yaklaşım, mitolojinin işlevinin sadece sanatsal çözümlenişi belirtmektedir. Halbuki mit, ancak birbirini bütünleyen pek çok 
niteliğin değişik bakış açıları doğrultusunda ele alınarak yorumlanabileceği çok karmaşık kültürel bir gerçekliktir (Eliade, 1993, s. 13).

Mitler araştırmacılar tarafından değişik tanımlarla hayat bulmaktadır. Bazı araştırmacılar miti, ilkel döneme ait toplumlarda ortaya çıkan halkın kolektif bilinçle kendine ait tarihi ve kendi kahramanlarını kurgulayarak fikir ve inançları bedenleştirdikleri geleneksel halk hikayelerini oluşturduklarını söylemektedirler (Tökel, 2000, s. 57). Kelime, masal, efsane veya söylem anlamlarında olan myth ve logia kelimelerinin birleșimi sonucunda oluşan mitoloji kavramı ayrıca Yunancada söylenen söz ve duyulan söz anlamına gelen mythos kelimesinden gelmektedir (Bolle, 2002, s. 13). Mitin söz veya sanat olarak da görülebileceğini belirterek, eski tarihlerde insanın varoluş sürecindeki zamansızlığı işaret ederken, yaşanmış olayların gerçek özüne inilmesini sağlayan bir tür sanat olduğunu belirtmektedir (Armstrong, 2006, s. 11).

İnsanlık tarihi ile birlikte başladığı varsayılan din hemen hemen her dönemde bireyleri ve dolayısıyla toplumsal düzeni etkileyen önemli bir unsur olarak karşımıza çıkmaktadır. Bunlara ilaveten, (Malinowski, 2000) insanlık tarihi kadar eskilere uzanan din unsuruna büyüyü de ekler. Bu noktada, mite dayalı gelenekler toplumda ilk anlatı, metin ve ideolojilerde var olmaktadır. Bu varoluş aynı zamanda şeylerin kökeniyle ve köksel olanı yansıtmakla ilgilidir. Dolayısıyla bu köksel bağ hem bir arada tutmak hem de egemenlik kurmakla ilişkilidir. Mitleri anlamak için gerçekleştiği anlara bakmak gereklidir. Bu gerçekleşme de ancak ritüeller ile anlatılan şeye dönüştüğünde yaşayan gerçeklikleri oluşturmaktadır.

Mitler her zaman sembolik ifadelerin soyut gerçeklikleri olarak kabul edilemezler. Dolayısıyla, mitlerin toplumları kendilerine çekebilmesinin temel sebebi içerdikleri bilginin doğruluğundan çok yarattıkları etkiler olarak kabul edilmektedir. Buradan yola çıkarak birtakım araştırmacılar da mitleri tanımlarken toplumdaki işlevlerini göz önünde bulundurarak sınıflandırmalar yapmaktadırlar (Koç, 2012, s. 219). Dolayısıyla, (Campbell J. , 1994) bu işlevleri dört farklı yönelimde ifade etmektedir. Birincisi metafizik-mistik yönelim olan işlevde mit bireylerde itaat, saygı ve huşu gibi duyguların beslendiğini ve nihai gizemin biçimlerinin varoluşunun kabulünü içermektedir. Daha sonra kozmolojik yönelimde mitin işlevi bir evren imgesi ortaya koymaktır. Buna bağlı olarak üçüncü yönelim olan toplumsal yönelimde işlev ise kurulu düzenin devamlılığı iken psikolojik yönelimde bu durum merkezileşen bireyin uyum kazanması şeklinde ortaya çıkmaktadır.

Tarih boyunca masallar ve mitler arasında da yakın bir ilişki olmuştur. Toplumsal hayatın şekillenmesinde önemli olan masallar mitlerden ve efsanelerden beslenmişlerdir. Mitler toplumsal olayları, mistik dünyayla birleștirerek fiziksel bağlantı olmamasına rağmen kutsal ve Tanrısal olaylarla, doğayla özdeşleşmiş görevler yaratmışlardır (Tekin, 2010, s. 125). Kısaca belirtmek gerekirse sözlü tarihten (masallar, halk öyküleri, vb.) beslenen mitler toplumların tarihsel geçmişlerini ve köklerine olan bağlılıklarını pekiştirmektedir.

Mitler, toplumların kökenlerine ait öykülerdir. Tarih (gerçek) ve mit (hayal) olarak bu iki zıt kavram, geçmişin hatırlanma biçimleridir. Bu sayede geçmiş içselleştiril ve sabitleștirilir. Assmann'ın da ifade ettiği gibi, köken olarak belirlenen mit ve gerçek olarak belirlenen tarih sayesinde toplumlar geçmişlerine bağlanmaktadırlar. Her iki unsur da hatırlama söz konusu olduğunda iç içe geçtikleri gözlemlenmektedir. Dolayısıyla, mit ve tarih, veya masal ve mit anlatıları tarihsel geçmiş bağlamında birbirlerinden beslenmektedirler (Assmann, 2015, s. 84). 
Doğaüstü varlık eylemleri, öykülerin kutsal ve gerçek kabul edilmesi, bir yaradılış olması ve bu yaradılışın toplumsal yapıyı yeniden üretmesi ve mitin nesnelerin kökenlerini bildirmesi bir mitte yer alması gereken 4 (dört) temel unsurdur. Gerçek anlamda dünyanın kurulmasını ve bu günlere gelmesini sağlayan mitler, kutsal olanın akınıdır (Keskintaş, 2013, s. 129; Eliade, 1993). Fiziki varlıkları anlamlandırmak isteyen insanın kökenlerine ait gerçek veya hayal olsun, geçmişi ile ilgili öykülere ihtiyaç duymaktadır.

Mitler, toplumsal bütünleşmenin aracı olan ayinler gibidir ve bu noktada efsane, dinsel öykü ve masallardan ayrılırlar. Efsaneler toplumun ihtirasını doyurmak amacıyla, masallar eğlence amacıyla anlatılmaktaydı. Dinsel içerikli öyküler de değer yargıları, saygı ve kutsal olanı yüceltmek amacıyla anlatılmaktaydı. Mit, bütün bu tanımlara uzak olup ancak ayinlerin, ahlaki kuralların ve törenlerin kutsallığı ve gerçekliğinin kanıtı konu edildiğinde devreye girmektedir. Bellek toplumun hafızasıdır. Mitler de gerçekçi bir şekilde yansıtılan geçmişin anlatılar aracılığı ile kuşaklar boyunca aktarılmasını ve geçmişin kaybolmadan yeniden yaşatılmasını sağlamaktadır. Mitlerin bir diğer görevi de ideolojik bağlamda toplumun kurallarını belirleyip kodlanmasını sağlamaktır (Malinowski, 2000, s. 99-105).

Mitler, kökenleri tarih açısından yoğunlaşmış olan geçmiştir. Geçmiş, döngüsel canlandırmalar ve tekrarlarla yeniden hayat bulurken, tarihin oluş sürecinde de içselleștiği görülmektedir. Mitler geçmişin izlerini günümüze ve geleceğe taşımaktadır. Tarihin ışığında var olanın anlamlanmasını, gerekli ve değişmez hale gelmesini sağlamaktadır (Assmann, 2015, s. 86). Dünyayı anlamlandırmanın yanında mitlerin bir diğer görevi mucize ve gizem gibi olaylarla geçmişle bağlantılı ve efsanelerle iç içe geçmiş bir inanç sistemi yaratmaktır.

İnsanların yaşadıkları dünya içinde geçmişle olan bağlarının kopmamasını sağlayarak, gelecek ile ilgili canlandırmalarda bulunarak geçmişle geleceği birbirine bağlayan bir köprü görevi görmektedir. Mitlerin inançla önemli bir bağı vardır ve ondan beslenmektedir. $\mathrm{Bu}$ bağ sayesinde toplumsal ve ahlaki düzen sağlanırken, insan topluluklarının topluma dönüşme aşamasında yol gösterirken, tarihsel geçmiş, ahlaki kurallar ve inanç sistemleri gibi konularda varoluşlarının devamı için bilincin oluşmasında önemli rol oynamaktadırlar.

\subsection{Sembolik Etkileşimcilik}

Varoluşundan bu yana insan, çevresini sorgulama ve anlamlandırma çabasında bulunmaktadır. Karşılaşmış olduğu değişimlerle dönüşümleri anlamlandırma aşamasında, yaşantısı ve çevresindeki anlam kalıpları ona ışık tutmuştur. Rastlantısal olaylar, kazalar veya doğal afetleri kendilerine göre anlamlandırarak bu yeni oluşumları anlam dünyalarına katmış ve paylaşılır olmalarını sağlamıştır. İnsan daima bir sembolik iletişim sürecindedir. Gündelik yaşantısını sürekli yeniden inşa ederek, toplumsallaşma süreci boyunca anlam dünyalarını diğerleriyle paylaşarak bir bütünsellik sağlamayı başarmıştır.

Chicago, 20. yüzyılın başlarında kentleşmeyi en yoğun yaşayan şehirlerden birisiydi. Şehir, olumlu ve olumsuz tüm yönleriyle ampirik çalışmalar yapmak için çok uygun bir noktadır. Sembolik etkileşim ve kent sosyolojisi bağlamında en önemli kaynaklar Chicago Sosyoloji Okulu'nun yapmış olduğu çalışma ve araştırmalar sayesinde literatüre kazandırılmıştır. Kent yaşantısını etnografi açısından inceleyen okul, genellikle düşük statü sahibi gruplar üzerinde çalışmış ve gündelik hayatı, detaylı bir şekilde birinci elden inceleyerek insan etkileşimini somut örneklerle gözler önüne sermiştir. Okulun en önemli iki öğretim üyesi 
olan Park ve Burgess, çalışmalarını 3 (üç) temel başlık altında kategorize etmişlerdir. İlk olarak coğrafi bölgeler bazında vakaları incelemişler, ardından kurum ve organizasyonları inceleyip son olarak da bireyler ve küçük gruplara inmişlerdir (O’Reilley, 2009, s. 32). Buna ilaveten, Deegan (2001) meslektaşlarına benzeyen ancak farklı bir sinıflandırma yaparak kentleri sosyal değişim alanı olarak ele almış ve eritme potası gibi bir metaforla irdeleyerek ırk ve ulus devlet ilişkilerini incelemiş̦tir (Deegan, 2001, s. 14-17).

Her iki sınıflandırmada ele alınan başlıklar, 20. yüzyılın ilk başlarında sosyolojik çalışmaları kurumsallaştırmış olması açısından önemli nitelik taşımaktadırlar. $\mathrm{Bu}$ bağlamda, söz konusu etnografi çalışmaları farklılaştıran temel unsur, Chicago Okulu'nun düşünürlerinin kendilerine özgü teorik yaklaşımlar ve metotlar kullanmalarından kaynaklanmaktadır. Yaklaşım ve metotlar farklılık gösterse de çalışmalardaki ortak olan, etkileşimci sosyal teorinin hepsi tarafından da kabul görmüş olmasıdır. Temelde Mead'in sosyal psikoloji bağlamındaki anlayıșına dayanan etkileşimci bakış, bireyleri hem fiziksel hem de benlik sahibi organizmalar olarak kabul edip ele almaktadır. Bu düşünce şekli benliği, kişinin kendisi ve çevresi ile etkileşimde olan bir süreç şeklinde analiz etmektedir. Bu çift taraflı etkileşim sayesinde ortak eylem türemiş olmaktadır (Mead, 1992).

Üretim süresi boyunca bilginin ne şekilde geliştiği, aktarımının nasıl gerçekleştiği, yaşanılan çevreden mi yoksa insan zihninde mi geliştiği gibi konularda pek çok tartışma mevcuttur. Benliğin sosyal ve bireysel boyutu da bu çalışmaların bir diğer kısmını oluşturmaktadır (Mead, 1992). Birtakım düşünürlere göre bilgi ve benlik sonradan kazanılmaktadır. Bir diğer düşünür ekibi de bu durumun tam tersi olarak bilginin doğuştan geldiğini savunmaktadır. Tüm bu felsefi çalışmalarla varlık ve bilgi konusunda tartışmalar ortaya çıkmaya başlamıştır.

Birbiriyle tam anlamıyla bağlantılı olmasa da Chicago geleneği, fiziksel ve düşünsel anlamda etkileşim durumunda bulunan teoriler bütünüdür. Deegan'ın (2001) da belirttiği üzere, "Mead, Dewey, Thomas, Park ve Burgess kombinasyonu, Small, Vincent ve Henderson gibi diğer Chicago teorisyenleri ile birlikte, Chicago etnografi çalışmalarını güçlendiren canlı ve esnek bir gündelik hayat teorisi yaratmıştır" (Deegan, 2001). Aynı zamanda, bir Chicago geleneği söz konusuysa, Okulun etnografi araştırmalarında doğrudan ilişkili olduğu ve kendine has teknikler kullandığını da belirtmek gerekmektedir. Bulmer'in (1984) belirtiği gibi, Okulu'nun en önemli mirası, öznel bakış açısıyla sosyal eylemin dayandığı bir yaklaşım oluşu ve yoğun olarak gerçekleştirilen alan araştırması, hayat hikayelerinin ve kişisel belgelerin toplamından oluşturulmuş bir araştırma geleneğini öne çıkarak sosyal bilimlere yaptığı katkıdır. Chicago Okulu, ellerinde bulundurdukları niteliksel verileri desteleyecek biçimde, istatistiksel araştırmalar yaparak, günlük tutma, haritalama, yaşam öyküleri, vaka incelemesi, dokümanların ikincil analizlerinin yapılması hatta araştırmacıların kendi otobiyografilerini de kaleme almalarıyla son derece çeşitli metodoloji bileşenlerini kullanarak literatür üzerinden, gündelik yaşamın yüz yüze ilişkilerini incelemiş ve sosyal hayatla ilgili açıklayıcı anlatılar üretmişlerdir (O’Reilley, 2009, s. 31).

\subsection{Toplumsal Cinsiyet Yaklaşımı}

Sözcüklerin anlamlarını kodlamak kolay denilecek bir durum değildir çünkü sözcülerin belirtmek istediği fikirlerin yanında bir de tarihleri vardır. Ne Fransız Akademisi ne de Ford profesörleri kelimelerin anlamlarını sabitlemeyi başaramamışlardır çünkü kelimeler insanın hayal gücü ve icatlarına bağlı olarak hareket etmektedir. 
Mary Wortley Montagu, kadına yönelik kınamalarını, "benim için o toplumsal cinsiyete mensup olmamın tek tesellisi, asla onların arasından biriyle evlenmeyeceğimin teminat altında olmasıdır" diyerek esprili bir ifade kullanmıștır. Bu sözü söylerken, dilbilgisi açısından bilerek hatalı referans kullanımına gitmiştir. Yüzyıllar boyunca insanlar, cinselliğe veya karaktere dair özellikleri çağrıștırırken metaforik imalarda bulunmuşlar ve bunu dilbilgisi terimlerini kullanmak suretiyle gerçekleştirmişlerdir. Bir örnek vermek gerekirse, Fransız Dili Sözlüğü Dictionnarie de la Langue Française tarafından şöyle bir kullanım öngörülmektedir: "Hangi cinse (genre) mensup olduğu, dişi (femelle) mi yoksa erkek (maale) mi olduğu bilinmeyen, duygularını bilemediğimiz fazlasıyla gizlenmiş bir kişiden bahsedilir " (Williams, 2005, s. 343).

Herhangi bir sözlükte ya da Sosyal Bilimler Ansiklopedisi Encyclopedia of the Social Sciences'da henüz yer almayan feministler, cinsiyetler arası ilişkiyi örgütlemeyi başarmışlar ve toplumsal cinsiyet bağlamında feminizm terimini en uygun şekilde kullanmışlardır. Dilbilgisi ile bağlantısı açısından, söz konusu sözcüğün açık ve net olmakla beraber, sınanmamış olasılıklarla dolu olduğu da bir gerçekti.

Ataerkil toplumlar değerlendirildiğinde, kadın için "zayıf cinsiyet" tanımını kullandıkları gözlemlenmekte ve kadının toplumsal rolünü bu ilkeye dayandırmak istemektedirler. Buna rağmen tarih boyunca bilim, kadını biyolojik bir varlık olma yönüyle ele almıştır. Oysa, emek bölümü ele alındığında, insanın anlamlı çalışmaları sonucunda ortaya çıkmış ve memeli hayvanlar gibi içgüdü temeli olarak ele alınmamışlardır (Cemal, 1996, s. 70). Kısaca belirtmek gerekirse, kadının ve erkeğin görevleri, toplumsal evrimin bir sonucu olarak değerlendirilmek zorundadır.

Simone de Beauvoir, Ana Tanrıça ne kadar da güçlü olsa sonuç olarak erkek tarafından yaratılmış bir idoldür fikrini savunmaktadır. Elbette o dönemde erkeğin kadın üzerinde kurduğu otoriteyi, kadının doğurganlığı karşısında dehşet duygusu içinde olup bu sebepten sinırlandırmalar getirdiğini de ilave etmeyi ihmal etmemektedir (Direk, 2009, s. 17-18). Erkek, doğa karşısında güç kazanmak isterken, korunacağı düşüncesiyle tanrıçalara tapsın veya tapmasın, biyolojik açıdan kadının kaderi, tarihsel süreçte her zaman bir düşüş izlemiştir. Ataerkil düzen içinde kadın, biyolojik değişikliklerinin ona yüklemiş olduğu sosyal rollerle toplumsal ortamda erkeğe bağımlı bir hale getirilmiştir.

Aynen ataerkil söylemlerde yer aldığı gibi medya da erkeği güçlü, akıllı ve aktif olarak nitelendirirken kadını zayıf, eksik ve pasif bir imajla sunmaktadır. Güçlü ve modern kadının ise güzelliği sayesinde var olabileceğini savunan, özellikle medya da bir hegemonya bulunmakta ve kadının diğer tüm özellikleri yok sayılmaktadır. Erkeğe göre kadının güçsüz olduğu savunulmaktadır (Arsan, Ünalan , \& Türkoğlu , 2009, s. 387). Cinsiyet ayırımcılığı söz konusu olduğunda yapılan pek çok çalışmada medyanın rolünün ne kadar büyük olduğu ortaya konulmaktadır (Güzel, 2014).

Etkenleri üzerine pek çok tartışma yürütülebilecek olan toplumsallaşma bireyleri belli koşullarda toplumsal pratiğe katılma noktasında teşvik etmektedir. Söz konusu teşvik zorlayıcılığı ile bireylerde toplumsal cinsiyet alanında cinsiyet rollerini uygulama biçimi, deneyimleri ve bedensel pratikler şeklinde ortaya çıkmaktadır. Dolayısıyla, toplumsal cinsiyet rejiminin kavramsallaştırılmasında yukarıda sıralanan toplumsal cinsiyet ilişkilerinin etkileşim durumları ve gündelik hayatta cinsiyet rollerini uygulama biçimleri toplumsal cinsiyet rejimi olarak açığa çıkmaktadır. Her kültürde ve yapıda farklı erkeklik ve kadınlık biçimleri olmakla birlikte toplumsal alanda yaygın bir şekilde 'hegemonik cinsiyet rolü olarak erkeklik' varlık göstermektedir. Bu noktada, hegemonik erkeklik 
kamusal bir uylaşıma dayanan ve ataerkil toplumsal ilişkilerin sürdürülmesinde başat bir rol üstelenen erkekliği ve kadınlığı bir arada kuşatan bir söylem ve kimlik biçimidir (Connell, 1998, s. 118).

Öte yandan toplumsal cinsiyet rollerinin etkileşimine benzer bir şekilde ifade edilişlerin sosyal ortamlarda ve çoğunlukla kültürel beklentileri ifade eder biçimde ortaya konulduğunun altını çizmek önemlidir. Burada sosyal ortam vurgusu toplumsal cinsiyet kavramının değişkenliğinin üzerine vurgu yapmaktadır. Dolayısıyla, birey toplumsallaşma ile üzerinde kendisine atfedilen davranışlara, düşüncelere ve yargılara göre davranır. Bir başka şekilde ifade edecek olursak, rol (Giddens, 2008) ifade ettiği şekliyle karşılıklı bir etkileşim ile hem bireyin toplumdan beklentilerini hem de toplumsal yaşamda bireye yüklenen davranışlar ve görevlerin toplamını içermektedir. Toplumsal cinsiyet rolü ise kültürel beklentileri de beraberinde taşıyarak bireyin yerine getirmesi beklenen cinsiyet ile ilişkili grup beklentilerinin bütünüdür (Dökmen, 2014, s. 18).

Benzer bir şekilde, toplum içerisinde var olan kadın ve erkek bireylerin statülerinin belirlenmesi hem kültürel hem de toplumsal değerlere göre şekillenmektedir. Dolayısıyla, kadın ve erkeğin statüsündeki eşitsizlikler ya da farklılıklar cinsiyet ile değil toplumsal cinsiyet ile ilişkilidir. Söz konusu eşitsizlikleri anlamak için cinsiyete dayalı iş bölümlerine bakmak önemlidir. Toplumsal iş bölümü kavramı bireyin yetenek ve tercihlerinden çok toplumsal cinsiyet normlarına göre şekillenmektedir. Erkeklik ve kadınlık sorumluluklarının yüklenmesinde toplumsallaşma 'toplum tarafından yüklenen roller' etkindir (Bhasin, 2003).

Bunlara ilaveten, (Kağıtçıbaşı, 2010) Türkiye'de genel olarak özellikle 1980 sonrasında eğitim alanındaki uygulamalar ve pratiklerle hakim hegemonik cinsiyet rollerinin pekiștirildiğini ve ataerkil sistemi destekleyen müfredatları devamlılığı koruduğuna vurgu yapmaktadır. (Connell, 1998)'in de üzerinde durduğu sosyal ortam ve etkileşim kavramlarından yola çıkarak, (Kağıtçıbaşı, 2010) kültürün taşıyıcıları olarak kadınların sosyal ortam olarak rollerinin evde olduğu yaklaşımın hakim ideolojinin devamlılığını sağlamak için önemli olduğunu ifade etmektedir. Burada önemli olan eğitim sisteminin ve müfredatlarının bu geleneksel roller üzerinden yapılan dayatmalardan bağımsız bir şekilde toplumsal cinsiyet eşitliği ile yeniden gözden geçirilmesi gerekliliğidir (Kağıtçıbaşı, 2010, s. 17).

Bireyci ve bütüncü sosyo-kültürel yapıların farklılığının Kabul edilmesiyle birlikte çeşitli sosyal birliktelik yapıların ataerkil bir yapıda varlığını sürdürdüğü ve kültürel açıdan ataerki ile yakından ilişkili olduğunu söylemek mümkündür. Bu bağlamda, sosyo-kültürel yapının incelenmesinde aile kavramının iktidar kavramı ile birlikte düşünülmesi önem arz etmektedir. Burada bireylere yüklenen roller ve statüler toplumsal cinsiyet kültürünü meydana getirir ve biyolojik temel üzerinde yükselen cinsiyet olgusunu cinsler arası ilişkilerin düzenlenme biçimleri olarak ortaya çıkar. Söz konusu düzenlemeler evrensel olmaktan uzak ve toplumsal farklılıklarla şekillenmekte ve kimliklerin oluşum süreçleri ile sosyalizasyonu doğrudan etkilemektedir (Türköne, 1995).

Toplumsal, tarihsel, kültürel ve psikolojik kurgu olarak 'kadının ötekileștirilmesi' çağdaş feminist teori tartışmalarının temel zeminini oluşturmaktadır. Kadınlık ve erkeklik kalıplarının karşıtlıklar diyalektiğinde şekillenmesi ile eril olanın kültür dişil olanın ise doğa ile şekillenmesi en temel dayanaklardandır. Dolayısıyla karşıt bir biçimde kurgulanan kültür ve doğa dolayısıyla erkek ve kadın hiyerarşik bir şekilde konumlandırılır (Donovan, 2005, s. 232). Öte yandan, sosyalist feministler de ise kadının 
yabancılaşması çalışma ve üretim alanının ev ile sınırlandırılması üzerinde tartışmalar yürütürken, kadınların sadece çalışarak kurtulacağı mitinin sorgulanmasına dikkat çeker. Simone de Beauvoir feminist kurama varoluşçu vizyonu kullanarak en büyük katkıyı, kadının kültürel ve politik statüsünü açıklamakla koymuştur (Donovan, 2005, s. 232). Bu bağlamda, de Beauvoir, söz konusu diyalektiğin sadece kültürel olmamakla değil bireyin kendi içinde varoluşu ile ilgili olduğu savını ortaya koymaktadır.

Bütün bu bilgiler ışığında feminizmin medya çalıșmalarında katkısı olarak medya ve toplumsal cinsiyet rolleri araştırılırken alımlamanın temel odağı oluşturduğunu söylemek mümkündür. Popüler kültür tartışmalarının da sıklıkla duraklarından birisi olarak kadın ve erkek imgelerinin TV programlarındaki dolaşımı bireylerin kendi yaşamlarına ilişkin duyguları ve popüler kültür iletileri arasındaki çelişkileri meşrulaştırmasıdır (Rakow, 1995, s. 15-37).

\section{Yöntem}

\section{1. Çalışmanın Amacı ve Literatüre Katkı}

Bütün bu bilgiler ışığında, çalışmada son dönemlerde dijital platform aracılığıyla Türk toplumu için popüler olan 2 (iki) farklı Netflix dizisi mitolojik anlatımı, sembolik etkileşim ve toplumsal cinsiyet açısından incelenmiştir. Söz konusu 3 (üç) ana kavramsal sınırlama 2 (iki) dizinin içeriği göz önünde bulundurularak benzer olay örgülerinin farklı tür aracılığı ile temsilini ortaya koyarken belirgin bir paradigma çerçevesinde tartışılmasını sağlama adına belirlenmiştir. Bu yolla çalışmanın temel amaç farklı iki anlatı üzerinden söz konusu olan Atiye ve Hakan Muhafız dizilerindeki baş kahramanın (Atiye dizisi içinkadın, Hakan Muhafız dizisi için- erkek) mitolojik ve efsanevi açıdan ortaya koyduğu 'Özel Olma Durumlarını' toplumsal cinsiyet rolleri açısında gerek sembolik gerekse olay örgüsü olarak ortaya koymaktır. Bu bağlamda literatürde karşılaştırmalı analizlerin sınırlılığı ve mit ve efsanevi anlatıların günümüz popüler Netflix dizileri aracılığıyla ortaya konduğu çalışmaların neredeyse yok denecek kadar sınırlı sayıda olması söz konusu araştırmanın güncelliğini koruması bakımından literatüre katkı koyacak niteliktedir.

\section{2. Çalışmanın Evren ve Örneklemi}

Çalışmanın evrenini Netflix platformunda yayınlanan Türkiye yapımı dizilerin tamamı oluşturmaktadır. Buradan hareketle, çalışmada amaçlı örneklem tekniği kullanılarak efsanevi olay örgüsü ve mitolojik öğeleri içerisinde barındıran farklı toplumsal cinsiyet rollerinin kahraman olarak baş rol aldığı 2 (iki) dizi olan Atiye ve Hakan Muhafız dizileri çalışmanın örneklemi olarak belirlenmiştir. Buna ilaveten çalışmanın örneklem birimi olarak her iki dizinin de ilk sezonunda yayınlanan tüm bölümler Atiye $(n=8)$ ve Hakan Muhafız ( $n=10)$ belirlenmiştir.

\subsection{Yöntem}

Çalışmada nitel araştırma yöntemlerinden belge analizi yöntemi kullanılmış ve bölümlere yönelik içerik analizi uygulanmıştır. İki dizinin toplam $18(n=18)$ bölümüne yönelik uygulanan içerik analizi hem göstergebilimsel açıdan hem de söylem analizi yöntemi ile ortaya konmuştur. Söylem analizinde içerik analizden kullanılan genel prensiplerden hareketle analiz kategorileri belirlenmiștir (Berelson 1952). Bu yolla, analiz kategorileri ile toplumsal cinsiyet rolleri açısından kadın-erkek kahraman olma, sembolik özellikler mitolojik anlatılar ve efsaneler ile ilgilidir. Söz konusu analiz kategorileri şu şekilde belirlenmiştir: 
1. Söylenen şeyle ilgili kategoriler:

- Mitolojik ve efsanevi anlatının referans noktası,

- Betimlemede kullanılan özellikler

- İşlenen değerler

2. Söyleme tarziyla ilgili kategoriler:

- Kullanılan atasözleri, nükteler ve hikaye anlatıların retoriği ile 'Efsanevi

Kahraman olmayı' betimleme şekilleri (sembolik etkileşim).

Bütün bu bilgiler ışığında çalışmada Göstergebilimsel çözümleme için Saussure'ün (1966) göstergenin üç boyutu paradigması betimsel nitel analizler yapılmak üzere kullanılmıştır. Tablo 1. Göstergelerin 3 (üç) boyutunu göstermektedir.

Tablo 1. Göstergelerin üç boyutu

\begin{tabular}{|l|l|l|l|}
\hline & Görüntüsel & İşaret Eden & Simgesel \\
\hline Gösteren & Benzerlik & Nedensel İlişki & Adet/Gelenek \\
\hline Örnekler & Resimler, heykeller & Ateş-Duman & Bayraklar \\
\hline Süreç & Görebiliriz & Çıkarım yapabiliriz & Öğrenmek zorundayız \\
\hline
\end{tabular}

Burada çalışmada anlamın iki dizinin 1. sezon bölümlerinde metinler olarak düşünülerek anlatımlarda nasıl iletildiği ve söz konusu metinlerde kullanılan göstergeler için gösterenler ve gösterilenlerin kombinasyonu şeklinde ele alınmıştır. Hiçbir metnin tek başına bir anlam ifade etmediği fikrinden yola çıkarak çalışmada medya çözümlemelerine yer verilmiştir. Çalışmanın temelindeki 'mit' antropolog Raphael Patai'nin Myth and Modern Man (1972)'deki kitabında açıkladığı şekliyle 'sıkça doğru olduğuna inanılan ilahi kahramanlar hakkında öykülerin formunu alarak işler' şeklinde kabul edilmiştir. Daha spesifik şekliyle çalışmada Patai'nin ilahi kahraman öyküleri olarak kabul edilen mit anlayışı Joseph L. Henderson'un (1964) kahraman mit anlayışı ile iki dizinin baş kahramanları için geçerli kabul edilmiştir. Henderson'da, kahraman miti şu şekilde açıklanmaktadır:

- Bir kahramanın mütevazi veya mucizevi doğumu,

- İnsan üstü kuvvetinin erkenden keşfedilmesi,

- Güç sahibi olması,

- Karanlık ve kötü güçler karşısındaki zaferi,

- İhanet veya kahramansı fedakarlığı.

\section{Bulgular}

Çalışmanın bulgularının ortaya koyulmasındaki sıralama yöntem kısmında detaylı bir şekilde ele alındığı şekliyle karşılaştırmalı analizler olarak şu ana hatlar şeklinde ele alınmıştır:

1. İki dizi için söylem analizleri

2. İki dizinin göstergebilimsel çözümlemesi

3. İki dizideki kahramanın toplumsal cinsiyet açısından kahraman mit anlayışı üzerinden çözümlenmesi.

\subsection{Atiye Dizisine Yönelik Söylem Analizleri ve Göstergebilim Analiz Bulguları}

Çalışmanın bu aşamasında Atiye dizisinin 1. sezonlarında yayınlanan toplam $8(n=8)$ bölümüne yönelik söylem çözümlemelerine ve göstergelerin göstergebilimsel analizlerine yer verilmiştir. Söz konusu söylemler analiz birimi içerisine 'mitolojik ve efsanevi anlatının 
referans noktası, betimlemede kullanılan özellikler ve işlenen değerler' açısından ele alınmıştır. Tablo 2 Atiye dizisine ait göstergelerin üç boyutunu göstermektedir.

Tablo 2. Atiye Dizisine ait Göstergelerin Üç Boyutu

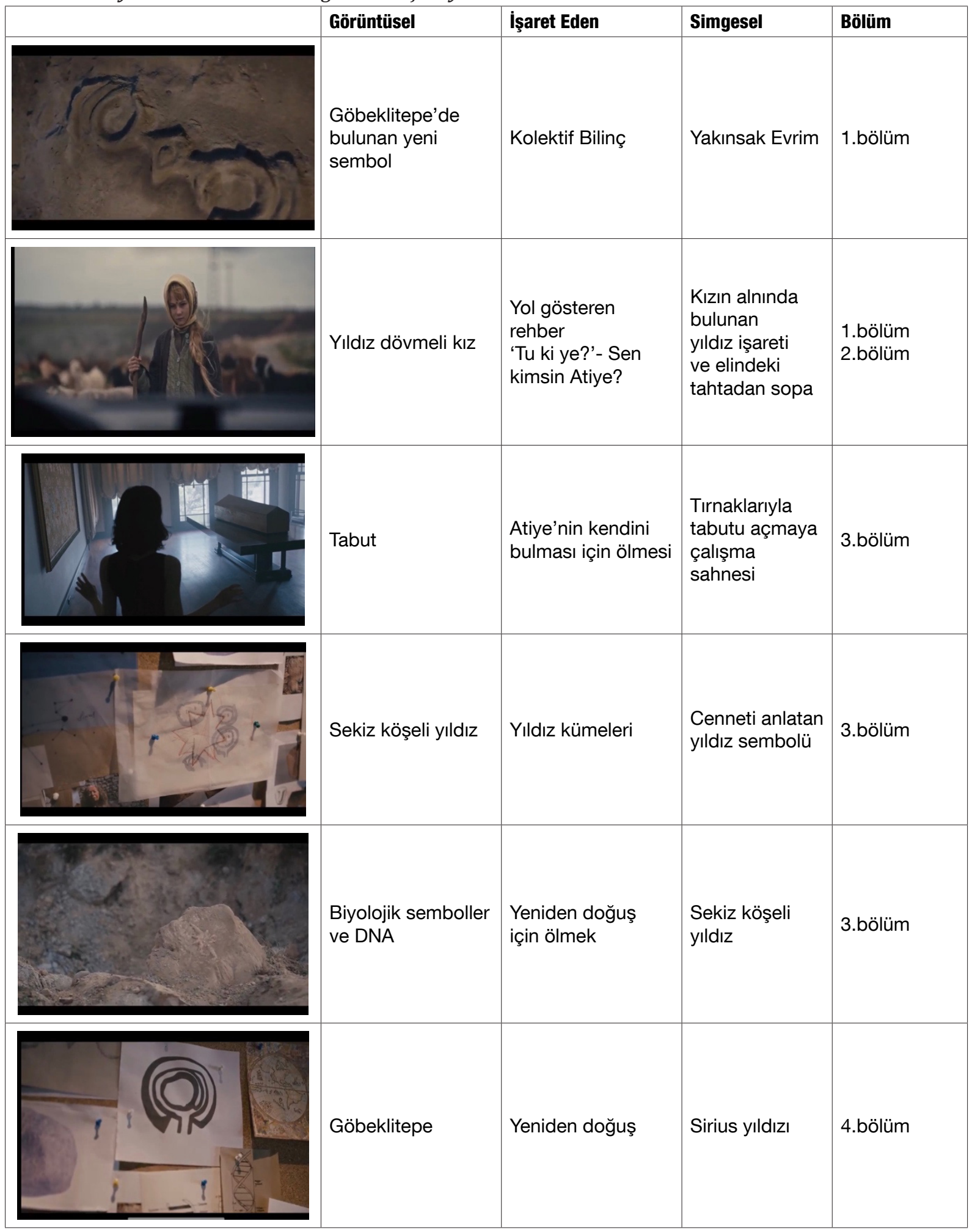




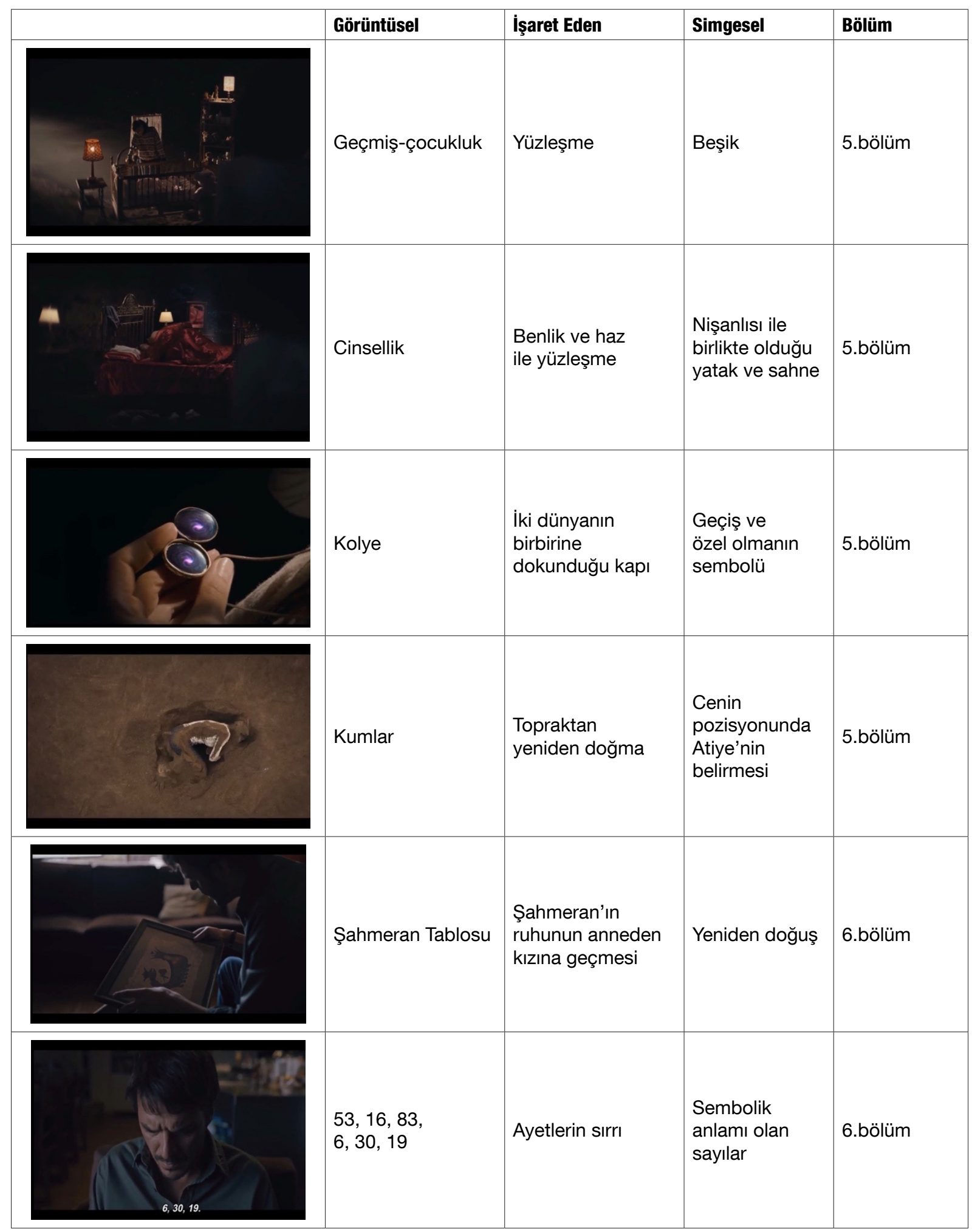

Tablo 2'de görüldüğü üzere Atiye dizisinin gösterenleri çoğunlukla 5 . bölümde toplanmaktadır. Bunun yanında gösterenlerin ve göstergelerin ortak odak noktası Göbeklitepe, takım yıldızları ve ilahi sembollerden oluşmaktadır. İşaret edilen en yaygın anlam ise kişinin kim olduğunu anlaması ve iki dünya arasındaki geçişin ölümün içerisindeki doğumun temsil edilmesi şeklindedir. Bu süreç içerisinde yol gösterici olanın Kuran'ı Kerim'deki ayetler olduğu ve görünenin ötesindeki anlamı bulma gerekliliği özellikle kahramanın 8 (sekiz) bölüm süresince sorgulaması gereken ve işaret edilen 
önemli olgular olarak karşımıza çıkmıştır. Bununla birlikte Atiye dizisinde ön plana çıkan efsanevi anlatılar şu şekildedir:

Her sır açığa çıkmak için çağrısını bekler. Demek ki vakti gelmiş evlat. (Atiye 2. bölüm)

Atiye'nin ikinci bölümünde profesör ve arkeolog Erhan arasında geçen diyalog bu söylemi içermekle bilinmeyenin bilinmesinde sır olarak düşündüklerimizi bilmemizde onu bilmek için çağırmamız gerektiği vurgusu yapmaktadır. Bilmediklerimizi öğrenmemiz için sabretmeyi ve her şeyin zamanı olduğu anlayışı ile aslında tasavvuf da bulunan tevekkül öğesi ortaya çıkarılmıştır.

Cevabını aradığın sorular var zannediyordum Atiye ama belli ki hayatını alt üst etmek istemiyorsun... Ne biliyorsun hayatının altının üstünden daha iyi olmadı̆̆ını. Șemsi-i Tebriz’i (Atiye 3. bölüm)

Atiye'nin üçüncü bölümünde sırları çözmek ve bilinmeyeni bilmek yolunda başına gelenlerden sonra hakikati aramaktan vazgeçtiği ve pes ettiği sahnede arkeolog Erhan'ın ona söylediği bu söz Şems-i Tebrizi'nin aşk romanındaki 14. kuraldır. Bu kuralda Şems, Hakk'ın karşısına çıkardığı değişimlere direnmek yerine, teslim olmaktadır. Bırak hayat sana rağmen değil seninle beraber aksın. Düzenim bozulur, hayatımın altı üstüne gelir diye endişe etme. Nereden biliyorsun hayatın altının üstünden daha iyi olmayacağını der. Bunu derken aslında karakter bir karar aşamasında olduğu alımlamasını yapmaktadır. Öyle ki Atiye için hiçbir şey artık eskisi gibi olamayacaktır ve yeni olanın nasıl olacağı bilinmeyen bir sırdır.

Kral ve kraliçelerin mezarlarında cevaplarınızı alacaksınız. (Atiye 4. bölüm)

Atiye'nin anneannesi Zühre ile gerçeğin ve bilinmeyen bilginin peşine çıktıkları yolda bu söz aslında gündelik yaşantımızda ve her daim yaşamda en nihai cevapların mezar taşlarında olduğunu vurgularken yeniyi bilebilmek için eskiyi terk etme gerekliliğini efsanevi bir anlatıyla ortaya koymaktadır.

Hoş geldin Atiye... Hissediyorum. Güneș doğuyor. Atiye sonsuzluk sonsuz zamana sahip olmak demek değildir. Zamansızlıktır. Sonsuz aydınlanmayı yaşamak istiyorsan geçmiş ve geleceği aklından çıkar șimdide kal demiş bir bilge Şems-i Tebrizi (Atiye 4. bölüm)

Atiye'nin diğer bölümlerinde olduğu gibi dördüncü bölümünde de Şems-i Tebrizi yer bulmuştur. Adıyaman ve Nemrut'un sembolik etkileşimi altında Atiye ve anneannesi Zühre'nin bu diyalogunda Zühre Atiye'ye zamanın nasıl önemli ve bir o kadar önemsiz olduğunu anlatmaktadır. Burada mitolojik kahraman olan Atiye geçmişle gelecekten sıyrılıp şu anda kalabildiği noktada gücünün ve kontrol edebileceği anın farkına varacaktır. Sonsuz olabilmek için bu gerekliliktir, gizli sihir şu andadır. Bununla birlikte Atiye'nin mağarada tutsak kaldığı bölümler ve sahnelerin tamamında kişinin kendiyle iç hesaplaşması ve yüzleşmesi olgusuna yer verilmiştir. Bu noktada öne çıkan bazı söylemler şu şekildedir:

\footnotetext{
Hakikati sadece zihninle anlayamazsın ki bırak ruhun yol göstersin sana ve hatırla ne olduğunu kim olduğunu hatırla. (Atiye 5.bölüm)

Sen onu gerçekten sevdin mi Atiye? Kendini sevmeyen bir başkasını sevebilir mi? (Atiye 5.bölüm) Söz niyettir Atiye. Ağzımızdan çıktığı an kendi gerçekliğini yaratmaya başlar. Peki sen söylediğin her sözün sorumluluğunu alabildin mi? (Atiye 5.bölüm)

Sen zaten yeterlisin ve kendini olduğun gibi kucakladı̆̆ında karanlıktan çıkarsın. (Atiye 5.bölüm)
} 
Tüm mağarada tutsaklık ve iç hesaplaşma anlatılarının ortak noktası kişinin kendi yaşadıklarını yaratmadaki aktif rolü üzerine olmuştur. Kendi hayatımızdaki yaratım sürecimizde sözlerimizin ve kendi gerçekliğimizin sorumluluğunun bizde olduğu vurgusu ile mitolojik kahraman geçmişiyle yüzleşmek zorunda kalarak kendisini en çıplak haliyle üvey kardeşi Cansu'nun geldiği ilk andan ona karşı duyduğu kıskançlık, erkek arkadaşı Ozan'a karşı hislerindeki ve ulaşamadığı sahte hazdaki sahtekarlık ve kendisini kabullenememesi ile yüzleşmiştir. Burada mitolojik kahramanın gerçek anlamla benlik bulabilmesi için bu hamaset duygularından arınması gerektiği ortaya konmuştur.

\begin{abstract}
İnsan sanır ki yılan tehlikelidir, zehirdir, şeytanın kendisidir. Ama aslında yılanlar bilgeliğin emsalidir. Yeniden doğuştur onların anlamı. Onlar kutsal olanı korumakla görevlidirler. Şahmeran yılanların güzel ve zarif kraliçesiydi. Yer altında saklı bir cennet bahçesinde hüküm sürerdi. Ama günlerden bir gün kendisi ve krallğ̆ bir insan tarafindan keşfedildi. Bal toplamaya çıkan insanlardan bir tanesi bir gün onun yöresine düştü. Şahmeran'la bir süre yaşadlktan sonra insan kendi dünyasında geri dönmeye karar verdi. Şahmeran'a bunu söylediğinde ise Şahmeran ona güvenerek bir söz verdirdi. Nerede yaşadığımızı ve saklandığımızı kimselere söylememelisin. Ĕ̆er söylersen sonumuzu getirirsin. Sonra ne olmuş der Erhan: İşler onun için hiç iyi gitmemiş. En güvendiği dostu ona ihanet etmiş ve insanlar gelip onu bulmuşlar ve cansız bedeninin mucizeler yarattığına inanarak onu öldürmüşler. Üzülme bir inanışa göre Şahmeran ölünce ruhu kızına geçer onda yaşamaya devam eder. (Atiye 6.bölüm)
\end{abstract}

Şahmeran hikayesi Atiye dizisi için hem içeriği hem de Şahmeran'ın kendisi gereği önemlidir. Çünkü Şahmeran mitolojik bir yaratılış olarak yarı kadın yarı yılandır. Atiye dizisinde Şahmeran hikayesi hem mitolojik kahramanlıkta anneden kız çocuğuna geçiş noktasında önemli olurken aynı zamanda da saklanan bilginin yanlış kişiler tarafından ele geçirildiğinde ortaya çıkabilecek felaketin emsali olarak dikkat çekicidir. Atiye'nin altıncı bölümünde Kuran-ı Kerim'den Yıldız Suresinin ayetlerine yer verilmektedir. Bu bölüme konu olan ayetler aynı zamanda şifreyi çözen sayıların yani 53, 16, 83, 6, 30, 19'un saklı ve doğru anlamlarıdır.

Onlar o büyük günde ki o gün insanlar aleminin Rabbinin huzuruna çıkacaklar: diriltileceklerini akıllarına getirmiyorlar mı? (Atiye 6.bölüm)

O diriden ölüyü ölüden diriyi çıkartıyor. Ve yeryüzünün ölümünün ardından yeniden canlandırlyor. Ki sizler de öyle çıkartılacaksınız. (Atiye 6.bölüm)

Ant olsun ki onu iniş esnasında Sitre ağacının yanı başında gördük ki onun yanında rahata erilecek bir cennet vardır o sırada sitreyi bürüyen bürünmüştür. Diriltileceklerini akıllarına getiremiyorlar mı? (Atiye 6.bölüm)

$\mathrm{Bu}$ ayetlerle bu bölümde üzerinde durulan efsanevi anlatı dirilmektir. Atiye eğer bu kapıdan geçebilirse mitolojik bir kahraman olarak ölüyü diriltecek güce sahip olacaktır.

İstemediğin hiçbir şey başına gelmez Atiye. Her ne olduysa sen öyle istediğin için oldu[...] Artık ne kadar güçlü olduğunu biliyorsun [...] Evren'de hiçbir şey bitmez Atiye sadece dönüşür [...] Her şeyin doğduğu yere git onu orada bulacaksın [...] Evet mümkün çünkü mümkün senin rızandır Atiye. Ruhunun yaraları iyileşmeye başladığında yönünü bulacaksın. (Atiye 8.bölüm)

Atiye'nin 1. sezonunun son bölümü olan 8. bölümde yeniden diriliş ve yaşananlara ne kadar güçlü etkilerle yön verebileceğinin farkına varırken, izleyiciye de yaşamlarında başına gelen her şey de kendi rızaları olduğu hatırlatılmaktadır.

Zaman belki bize söylendiği gibi doğrusal değil oğlum, belki geçmiş ve gelecek birbirinin içinde erimiş ve biz bir düş bir yanılgı içerisindeyiz. Sana bin yıllardır saklanmış bir bilginin kadim bir rehberliğin anahtarını veriyorum. Bunun peşinde olanlardan kendini koru. Onları yıllar önce yanılttım. Benden çaldıkları defterde bu kapının yerini bulduklarını sandılar oysa aradıkları haritayı senin vakti geldiğinde bulman için sakladım. Kapıyı bul, Atiye'nin kurtuluşu buna bağlı. Atiye gelecek demek oğlum karanlığa gömülü aydınlık o, onu koru. (Atiye 8.bölüm) 
$\mathrm{Bu}$ anlatıda arkeolog Erhan'a babasının ögüdü de yine mitolojik kahraman Atiye'nin karşılaştı̆̆ı anlatılarla aynı noktayı işaret etmektedir. Aslında zaman bizim belirlediğimizdir. Hiçbir şey yok olmaz sadece zaman değiștirir. Geçmiş zannettiğimiz geleceğimiz olabilirken gelecek sandığımız ise geçmişin içerisinde kaybolmuş olabilir.

Merak etme her șey olması gerektiği gibi hepimiz ilahi planın parçalarııız, hepimiz birbirimizin devamiyız. Sen olup bitenlere mani olamazdın ama olacakları yaratmak senin elinde. Sana bir hediye verildi Atiye, sen gerçekten istediğin her şeyi yapabilirsin. (Atiye 8.bölüm)

Atiye son sahnede gücü ve farkındalıkları ile hem korku hem de endişe yaşarken bu anlatı ona ilahi bir plan olduğunu ve bizim bu planın içerisinde birbirini takip eden şeyler yaşadığımız geçmişi değiştiremeyeceğimiz gibi geleceğe yön vermekte rızamızın olması gerektiğinin altı çizilmiştir.

\subsection{Hakan Muhafız Dizisine Yönelik Söylem Analizleri ve Göstergebilim Analiz Bulguları}

Çalışmanın bu aşamasında Hakan Muhafız dizisinin 1. sezonlarında yayınlanan toplam $10(n=10)$ bölümüne yönelik söylem çözümlemelerine ve göstergelerin göstergebilimsel analizlerine yer verilmiştir. Söz konusu söylemler analiz birimi içerisine 'mitolojik ve efsanevi anlatının referans noktası, betimlemede kullanılan özellikler ve işlenen değerler' açısından ele alınmıştır. Tablo 3 Hakan Muhafız dizisine ait göstergelerin üç boyutunu göstermektedir.

Tablo 3. Hakan Muhafız Dizisinin göstergelerinin üç boyutu

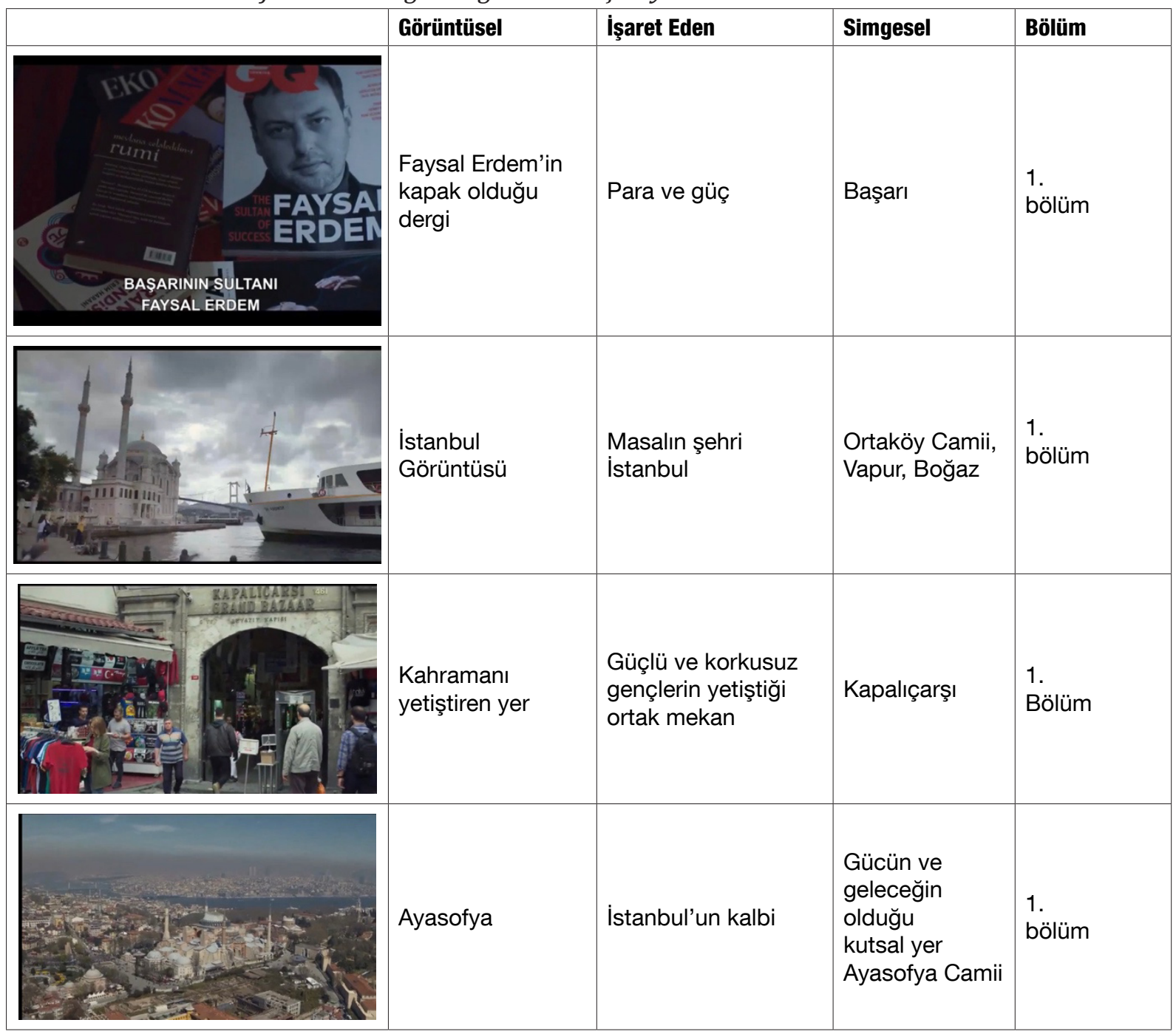




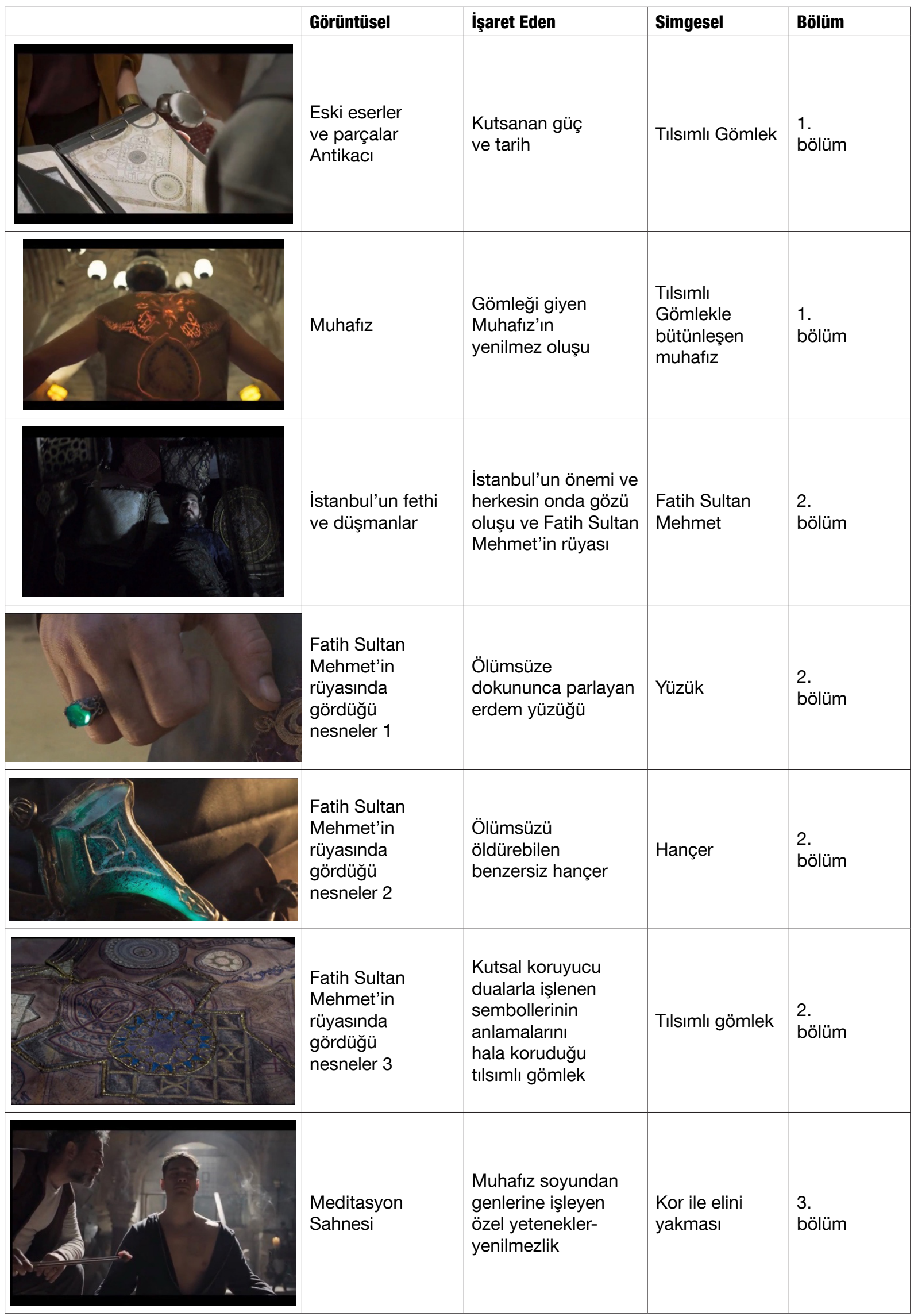




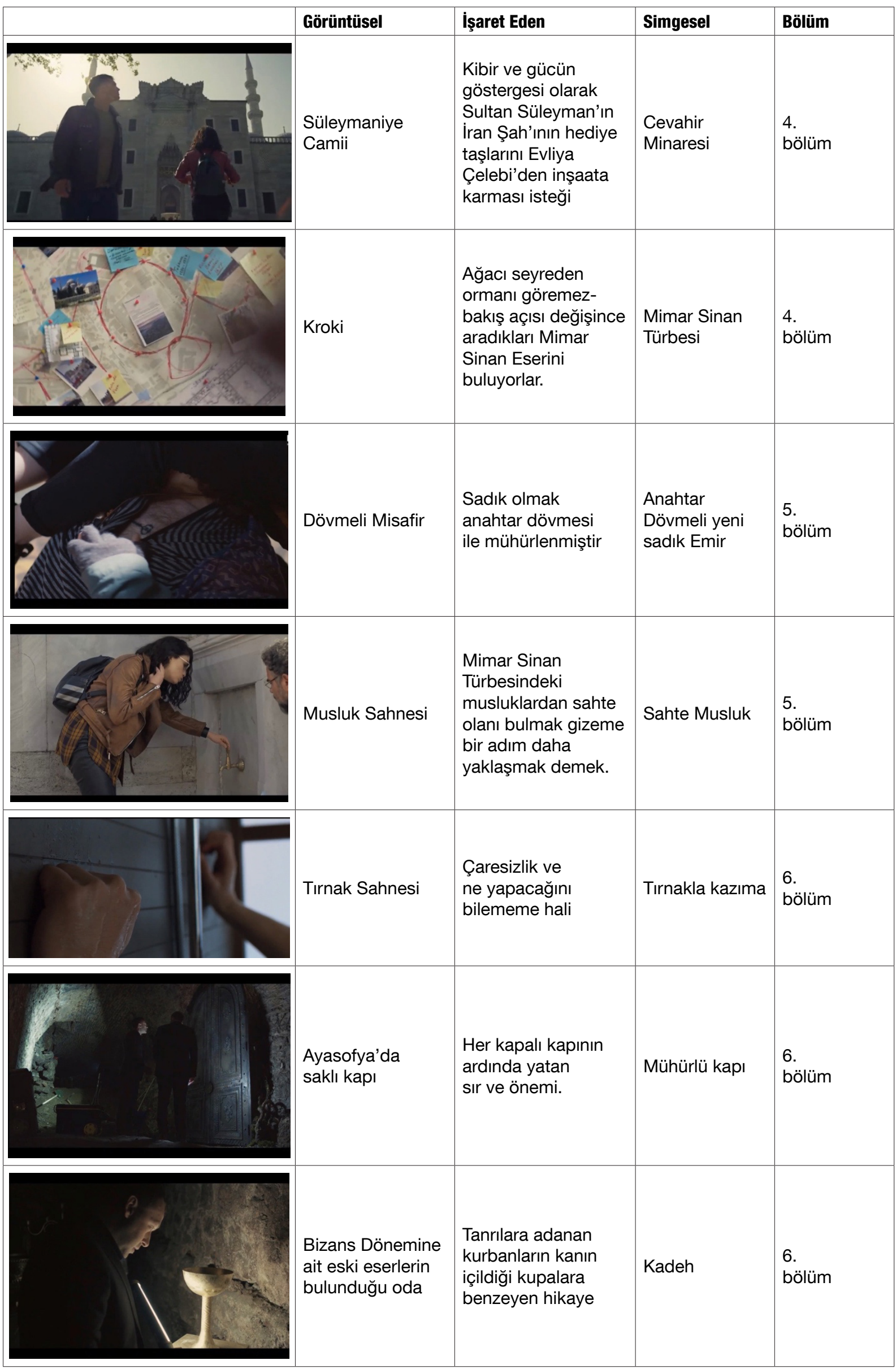




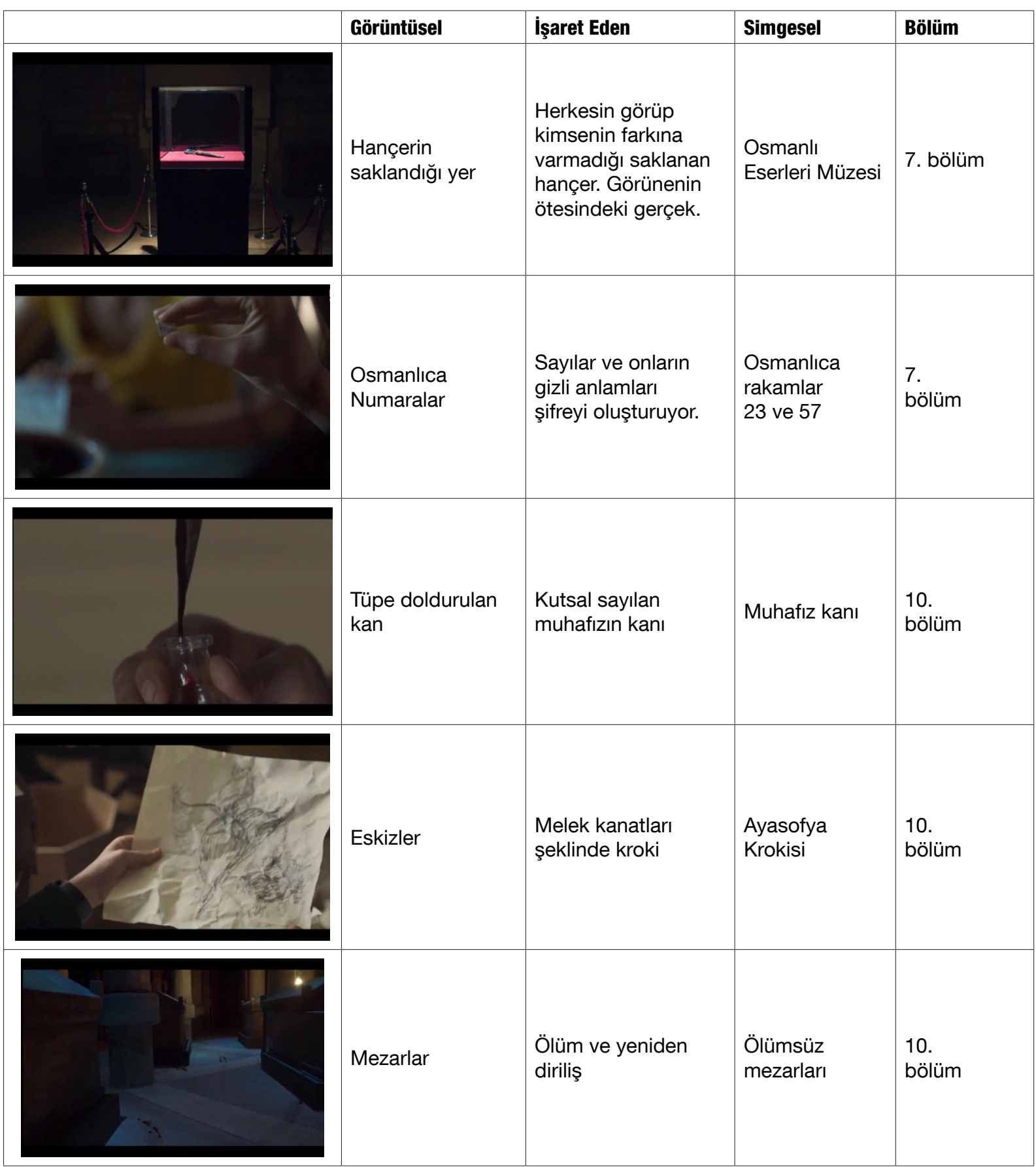

Tablo 3'de görüldüğü üzere Hakan Muhafız dizisinin gösterenleri çoğunlukla 1. bölümde toplanmaktadır. Bunun yanında gösterenlerin ve göstergelerin ortak odak noktasını Osmanlı tarihi ve Osmanlı padişahlarının döneminde yapılan tarihi eserler oluşturmaktadır. İşaret edilen en yaygın anlam ise yaşamın kalbi olarak kabul edilen İstanbul için savaşan iki kutup ve savaş içerisinde özel yeteneklere sahip iki mistik yaratılışın karşı karşıya gelmesidir. Bu süreç içerisinde yol gösterici olanın kutsal emanetler ve ona sadık olanlar olmuştur. Burada kahraman için önemli olan sadık olanların sonsuz sadakati ve genlerinden gelen özel yetenek olmuştur. Bununla birlikte Hakan Muhafız dizisinde ön plana çıkan efsanevi anlatılar şu şekildedir:

Hakan oğlum her şeyin yenisi makbul değildir. Bak şu çarşının 600 yıllık tarihi var. (Hakan Muhafız 1. bölüm) 
Hakan Muhafız'ın birinci bölümünde antikacı Neșet ile konuşması Neşet'in bu sözü aslında geçmişin ne kadar kıymetli olduğunu ve içerisinde barındırdığı tarih ile anlamlı olduğunu vurguladığı bir söylemdir. Burada vurgu tarihin ve eskinin kıymetidir ve onun yerini hiçbir şeyin tutmayacağıdır.

\begin{abstract}
Ayasofya mucizeler ve gizemlerin gerçek olabileceğini göstermek ve biz fanilere edebi bir an yaşatmak için inşa edildi. Onun restorasyonunda yardımcı olabilmek bir iş değil onurdur. Napolyon'un meşhur bir sözü vardı eğer dünya tek bir ülke olsaydı başkenti İstanbul olurdu der. Ben bu sözü şöyle değiștiriyorum. Eğer dünya bir insan olsaydı kalbi muhakkak Ayasofya olurdu. (Hakan Muhafız 1. bölüm)

1500 yıldır ayakta burası, bunun ne kadar uzun bir süre olduğunu anlayabiliyor musun? Bak Konstantin de buradaydı, Fatih de, hepsi kendi savaşını verdi. Ama sonra ne oldu, ne kaldı geriye, Ayasofya. (Hakan Muhafız 1. bölüm)
\end{abstract}

Ayasofya'nın restorasyon ihalesini kazandığı anda basın toplantısında bu sözü söyleyen Faysal aslında İstanbul'a tarihler boyunca nasıl önem atfedildiğini vurgulamaktadır. Bununla birlikte ölümsüzlerin mezarlarının bulunduğu yer olan Ayasofya Camii ve tabii ki mitolojik bir kahraman olarak ölümsüz olsa dahi Faysal'ın yegane aşkı Rüya'nın bulunduğu yer olmasıyla Ayasofya hem dünyanın hem İstanbul'un hem de Faysal'ın dünyasının kalbidir.

\begin{abstract}
Fatih Sultan Mehmet Konstantin'i fethettikten kısa bir süre sonra şehrin içinde düşmanları olduğunu fark etti. Kendilerini İstanbul'u ve dünyayı fethetmeye adamış tam 7 ölümsüz, nereden ve ne zaman geldiklerini kimse bilmiyor. Ama bütün kitlıklar, seller ve depremlerin ucu onlara dayanıyordu. Bir gece Fatih bir rüya gördü, tıpkı senin benim gibi görünen bu ölümsüzlerin nasıl ayırt edilip öldürüleceği ona malum oldu. Fatih rüyasında 3 nesne görmüştü: ilki ölümsüze dokununca parlayan erdem yüzügü, ikincisi ölümsüzü öldürebilen benzersiz bir hançer ve üçüncüsü bu ölesiye savașta bir zırh görevi görebilecek bir gömlek. Kutsal koruyucu dualarla dokunmuş tılsımlı gömleğin bugün bile hala gizemini koruyan sembolleri var. Bildiğimiz tek şey gömleğin muhafızla arasında özel bir bağ olduğu. Yani Fatih'in ölümsüzleri öldürmek için yeteneklerinden, gücünden ve saf kalbinden ötürü seçtiği adamla sen Hakan muhafizların sonuncusu sensin. (Hakan Muhafiz 2. bölüm)
\end{abstract}

Burada Kemal Hakan'ı muhafız olmasıyla ilgili bilgilendirirken iyi ve kötü ikililiğinden yararlanıyor. Burada iyi olan yani muhafız soyu İstanbul'u kurtarmaya çalışırken tüm kötülüklerin sorumlusu olarak ölümsüzler gösteriliyor. Burada kötülükleri durdurma sorumluluğu ise Osmanlı padişahı Fatih Sultan Mehmet'e malum olan rüyada gizli ve aslında kötülüğün durdurulması için kuşaklara aktarılan muhafız sorumluluğunun da başlangıcı onda saklıdır.

- Öfke rüzgar gibidir bir süre sonra diner ama.. Dallar çoktan kırılmıştır.. Mevlana Celalettin Rumi (Hakan Muhafız 3. bölüm)

- Gömleğin kendine göre bir iradesi var bunu zamanla göreceksin. Gömleğin seni koruması için duygularına hakim olmayı öğrenmen gerek. Onun gücüne inan, kendi gücüne ve güvenine inan. (Hakan Muhafı 3. bölüm)

- Gömlekle bir ol Hakan, gömlekle bir ol! (Hakan Muhafız 3. bölüm)

Kemal ile muhafız arasındaki meditasyon eğitimi sırasında şu olgu öne çıkarılmaya çalışılmaktadır. Öfke kişileri hızlıca sürükleyip varmak istediği yere götürebilir fakat dindiğinde geçtiği yollar artık eskisi gibi olmayacaktır. 0 yüzden o yolda sabırla öfkeden siyrılarak yürümek gereklidir. Her şeyin zamanını beklemek en doğrusudur.

- Bu şans değil onun kaderi. Ölümsüzler ve Muhafız'lar birbirlerine doğru çekilirler. Tıpkı mıknatısın kutupları gibi. (Hakan Muhafız 4. bölüm) 
Burada da tıpkı önceki birinci ve ikinci bölümde olduğu gibi iki farklı kutuplaşmadan bahsedilmektedir. İyilik için savaşan muhafız soyu ve kötülüklerin nedeni ölümsüzler. Bu kutuplar o kadar zitlık içerisindedirler ki daima birbirlerini çekerler.

- Sinan eserlerinde çiniyi çok sık kullanır ama böyle değerli bir taşı açıkçası kullandığını ben de pek zannetmiyorum. Yalnız şöyle ilginç bir hikaye de var. Evliya Çelebi'de bahseder bilmiyorum sizin ișinize yarar mı? Süleymaniye'nin temeli kazıldıktan sonra Sinan uzunca bir süre bekler, zemindeki kayaların iyice oturmasını istiyor çünkü. Iran Şahı'nın da bu durumdan haberi yok, zannediyor ki Osmanlıda para bitti inşaat o yüzden durdu. Tutuyor iki üç sandık mücevher gönderiyor Süleyman'a. Sultan Süleyman'da kızıyor bu duruma, alıyor mücevherleri Sinan'a veriyor. Al bunları inşaatın harcına kat diyor. Sinan'da alıyor bu mücevherleri minarelerin birisinin harcına katıyor. Cevahir Minaresi. (Hakan Muhafız 4. bölüm)

Bu hikaye ile anlatılmak istenen aslında en önemli zannedilenin bile küçük bir taştan ibaret olması iken hikayede kibirle ve öfkeyle hareket eden iki hükümdar görülmektedir. Birisi İran Şah'ı diğeri ise öfkelenen Sultan Süleyman. Bu mistik hikaye aslında güç ve iktidarın icraat ile ilişkisini de ortaya koymaktadır. Mühim olan güç ile sahip olduklarını hangi amaçlar için kullandığındır. Onlar zanaatkarların elinde anlamlı bir nesneye dönüşebilir.

- Ağacı seyreden ormanı göremez derler, bir detaya takılıp kalıyoruz. (Hakan Muhafız 4. bölüm)

Burada görünenin ötesini görmek için bakış açısının değiştirilmesi gerektiği üzerinde vurgu bulunmaktadır. Görebilmek için bakmak yeterli değildir. Doğru yerden bakmak önemlidir.

- Şah damarımdaki kan gibi usul, şairin topu gibi gürleriz biz faniyiz sadık olanlardanız. (Hakan Muhafız 5. bölüm)

- Yaptığın işi gönlünde hissedersen, ırmaklar çağlar içinde. Mimar Sinan. (Hakan Muhafiz 5. bölüm)

- Emir: Babam hep şunu söylerdi: Hayatta bir seçemediğin bir de seçebildiğin alem vardır. (Hakan Muhafız 6. bölüm)

Sadıkların parolası olarak kabul edilen bu sözler aslında sadık olanların gelip geçiciliği ile birlikte sessizce kendilerini gizleyerek tam bir adanmışlıkla vakitlerini beklediklerini, vakitleri geldiğinde ise tam anlamıyla kendilerini muhafız için feda edebileceklerinin temsilidir. Burada vurgulanan en büyük değer sadakat olmuștur. Bunun yanında Hakan Muhafız'ın beşinci ve altıncı bölümünde sadıklarla ilgili gönüllülük ve adanmışlık değerleri ön plana çıkmaktadır. Gönüllük ve adanmışlıkla yaptıkları her işte tam motivasyonla sonuna kadar muhafıza hizmet etmeleri üzerine vurgu yapılmaktadır.

- Balzac'tan alıntı yapıyor- Her büyük servetin arkasında bir suç gizlidir. (Hakan Muhafız 6. bölüm)

Bu sahnede gazetecinin Faysal'ın peşine düşmek için Hakan'ı ikna etmek için Faysal'ın suçlu olduğuna inandırması gerekmektedir. Bunun için de her ekonomik gücün suçtan geçtiğini Balzac'tan alıntı yaparak vurgulaması dikkat çekmektedir.

- Faysal: Bütün mutlu ailelerin hikayeleri birbirine benzerler, mutsuz ailelerin ise her birinin hikayesi başkadır demiş Tolstoy. (Hakan Muhafız 7. bölüm)

- Tecrübe denen şey bütün hataların toplamıdır. (Hakan Muhafız 7. bölüm) 
Hakan Muhafız'ın yedinci bölümünde en fazla vurgulanmaya çalışan toplumsal değer tecrübe ve eşitsizlik olmuştur. Mutluluğun tek bir tanımı olduğunu ve tekdüzelikle o tekdüze sistemdeki şeylere sahip olduğumuzda birbirimizin aynısı olduğumuzu söylerken mutsuzluğun farklılıklardan geldiğinin altını çizmektedir.

- Bu dünyadaki acıların sebebi insanlardır. Nefretle öfkeyle açgözlülükle yaptıklarlnıza bir bak. Insanların sadece Ayasofya'ya yaptıklarına bakman yeter. Kaç kere yıkıldı yağmalandı. İster inan ister inanma biz sadece birkaç çer çöp getirdik. Yangını başlatan körükleyenler de insanlardı hep. (Hakan Muhafız 10. bölüm)

Hakan Muhafız'ın birinci sezonunun son bölümünün en son sahnesi aslında tüm toplumsal değerleri ve olguları barındırması açısından çarpıcıdır. Bu sözlerle ölümsüz yani Faysal açgözlülüğe, öfkeye, nefrete dikkat çekerken insanların korumak için uğruna savaş verdikleri İstanbul'a yaptıkları kötülükleri de hatırlatmaktadır. Öyle ki kötü sanılan ve kötülüğü hep karşıda aramak insanların en büyük hatalarından birisi olmuştur.

\subsection{Toplumsal Cinsiyet Açısından İki Mitolojik Kahramanın Değerlendirilmesi}

Çalışmanın bu aşamasında iki mitolojik kahramanların (Atiye ve Hakan Muhafız) Joseph L. Henderson'un (1964)'ün kahraman mit anlayışı için geçerli kabul edilen 5 (beş) özelliği üzerinden karşılaştırılması yapılmıştır.

\section{i. Bir Kahramanın Mütevazi veya Mucizevi Doğumu:}

İki mitolojik kahraman içinde mütevazi doğum söz konusu olmuştur. Dizilerde mitolojik kahramanlar doğumundan çok sonra doğumları ile ilgili gerçeği keşfetmişlerdir. Burada toplumsal cinsiyet rolleri açısından öne çıkan en önemli bulgu iki kahramanın temsil ettiği mucizevi aktarımdır. Şöyle ki, Atiye dizisinde anneden-kız çocuklarına geçen mucizevi yetenekler matriarkal sistemi çağrıștırırken, Hakan Muhafız dizisinde yetenekler genlerle babadan oğula aktarılmaktadır. Bu durum ise patriarkal sistemin temsili olarak kabul edilebilir. Kadın kahraman için genlerden aktarılan yeteneğin inkarı söz konusu olur iken (Atiye'nin annesinin yeteneklerini reddetmesi üzerine ondan doğan kız çocuğunun sorumluluğu alması), erkek kahraman genlerinden gelen soyunun sorumluluğunu koşulsuz kabul etmektedir. Burada sistemin devamlılığı için erkeklik daha sadık olarak öne çıkarken kadınlıkta mucizevi güçlerden doğan korku neticesinde inkar etme olgusu ortaya konmuştur.

\section{ii. İnsan Üstü Kuvvetinin Erkenden Keşfedilmesi:}

İki mitolojik kahraman için de insan üstü güçlerin keşfedilmesi geç olmuştur. Bu süreç kadın kahraman olan Atiye için erkek kahraman olan Hakan Muhafı'dan daha sancılı olarak gerçekleşmiştir. Toplumsal cinsiyet rolleri açısından kadın kahraman Atiye'nin yavaş yavaş belirginleşen insan üstü kuvvetlerini anlamlandırma sürecinde karşılaştığı en büyük engel 'kadın' olmasıdır. Öyle ki sürekli 'nişanlandın sen artık aklını başına topla' şeklinde telkinlerle hislerinin ve yaşadıklarını dile getirmemesi gerektiği söylenmektedir. Hatta bu süreçte kadın kahraman olan Atiye psikolojik sorunları olduğu gerekçesiyle tedavi edilmeye başlanmıştır. Kimsenin duymadığı sesleri duyan ve görmediklerini gören Atiye psikiyatr tarafından 'Kendini özel hissetme ve bulma' noktasında paranoid şizofren teşhisi ile karşı karşıya kalmıştır. Atiye bir kadındır ve evlilik arifesinde kendisine çeki düzen vermesi gerekmektedir. Diğer taraftan erkek kahraman olan Hakan muhafız olduğunu ve insan üstü yeteneklerinin varlığını öğrendiğinde hayatındaki en önemli kişileri kaybetmiştir. Atiye'nin aksine insan üstü yeteneklerinin anlamını bulmak üzere hem ruhsal hem de fiziksel bir yola çıkma ve bu yolda yüzleşmelerle karşı karşıya kalmak yerine sadık olan Kemal ve Zeynep'in ona altın tepsiyle sunduğu bilgileri dinleyerek insan 
üstü güçlerini keşfetmesi gerekmiştir. Hakan bu süreçte hazırbulunmuşlukla kahramanlık gömleğini giyerken kadın kahraman Atiye bu yolda zaman zaman kendinden bile şüpheye düşerek yalnızlık ve yüzleşmeler sonucunda insanüstü gücünün farkına varmış ve olayları anlamlandırmaya başlamıștır.

\section{iii. Güç Sahibi Olması:}

İki kahraman içinde güç sahibi olmak farklı anlamlara gelmektedir. Bu noktada iki dizinin temelini oluşturan toplumsal değerler ve atıf noktasının farklılığı güç ve gücün temsilindeki farklılıkların anlamlarını da ortaya koymaktadır. Atiye için güç kendini bilmek, keşfetmek ve evrende sonu olmayan enerjiyi rızanla yönlendirebilmek iken, Hakan Muhafız için güç erkeklik temsillerinde sıklıkla karşımıza çıkan 'korumak-koruyup kollamak' şeklindedir. Hakan İstanbul'u korumalıdır. Çünkü İstanbul ve insanlar acizdir, kötülükler ve tehditlerle karşı karşıyadır. Bu güç sahibi olduğunda Hakan kendini sorgulamamaktadır. Çünkü bu güç ona atalarından geçmiştir ve onda olması normaldir. Onun bu gücünü destekleyenler yani sadık olanlar da onun gücünden güç almaktadır. Diğer taraftan Atiye gücünün farkına varabilmek için ruhsal bir yolculuğa sürüklenmiş ve etrafındaki herkesin karşı çıkmalarına rağmen o yolculukta yüzleşemem dedikleriyle yüzleşip, sonsuz fedakarlıklarla gücünü eline alabilecek noktaya ulaşmıştır. Yani kadın kahraman güç sahibi olabilmek için güçlü bir karakter sergilemek durumunda kalmıştır.

\section{iv. Karanlık ve Kötü Güçler Karşısındaki Zaferi:}

Her iki kahraman içinde karanlık ve kötü güçlerle savaşmak gerekmektedir. Her iki dizinin 1. sezonları için dizilerin devamlılığı adına mutlak zaferlerden bahsetmek mümkün olmamakla birlikte Atiye gizli kapıyı saklamayı başararak üvey kardeşi Cansu'yu öldüren kötü güçlere karşı onu diriltmeye rıza gösterip başarılı olmuştur. Hakan Muhafız için ise ölümsüzün karşısındaki başarısızlığı 'bir kadına duyduğu özel duygular' olmuştur. 0 kadını kurtarmak adına ölümsüze karşı yenilmiştir.

\section{v. İhanet veya Kahramansı Fedakarlığı:}

Toplumsal cinsiyet rolleri açısından diğer önemli bulgu ise kadın kahramanın fedakarlığının çok daha büyük olması gerektiğidir. Atiye çıktığı yolda kendi geçmişinden ve geleceğinden fedakarlık ederek üvey kardeși Cansu'yu diriltmiștir. Ondan öncesinde de yaşadıklarına destek olmayan ailesi tarafından yalnızlığa sürüklenmiş ve onların istedikleri hayatı yaşamak için onu sonsuz bir güçle çeken Göbeklitepe sembolünü araştırmayı ve tutkusu olan çizimi bırakmak zorunda kalmıştır. Bütün bunlardan sıyrılıp hislerini takip etmek için ise ona biçilen rolden 'düğününden kaçarak' geleceğini feda etmiştir. Hakan Muhafız için ise ihanet İstanbul'a karşı olan sorumluluğudur. Sevdiği kadını kurtarmak için insan üstü güçlerini feda etmiştir. Tılsımlı gömlek ve hançeri ölümsüze teslim ederek sevdiği kadını kurtarmıştır.

\section{Tartışma ve Sonuç}

Mitolojik hikayelerin, efsanelerin ve kahramanlarının anlatıları çoğunlukla erkek egemen bir anlayışla ortaya konulmaktadır. Son dönemlerde oldukça popüler olan Atiye ve Hakan Muhafız dizileri tam da bu noktada farklı bakış açılarını iki farklı cinsiyet yönünden ele alması bakımında önemli bir veri sunmaktadır. Buradan hareketle bu çalışmada mevcut toplumsal cinsiyet anlayışlarının gerek geçmişte gerekse yeni yapımlarda varlığını sürdürdüğünü söylemek yerinde bir sonuç olacaktır. Bununla birlikte mitolojik anlatılar bakımında söz konusu iki dizinin odağı ve referans noktaları farklılaşmaktadır. Erkek kahramanın gücü daha fazla Osmanlı ve padişahların hikayeleri eserleri ile resmedilip ilişkilendirilirken, kadın kahramanın gücü için dini ve ruhani doktrinler söz konusu 
olmuştur. İki dizi içinde öne çlkan mekanlar ve yerler çekildikleri bölgenin tarihi eserleri şeklindedir. Buradan hareketle sembolik açıdan iki dizi bazı olguları sembolleștirme noktasında önemli katkılar sağlamıștır. Fantastik kurgusu ve olay örgüsüne rağmen iki dizide de hayata dair ögütlerin ve hayatı sorgulamaya iten hikaye ve söylemlere sıklıkla başvurulması ideolojik açıdan da önemli veriler ortaya koymaktadır. Mitolojik kahramanların tarih anlatılarından ve masallardan çıkarak gündelik hayatın tam içerisinde popüler dizilerle yeniden dolaşıma girmesi noktasında da iki dizi önemini korumaktadır. $\mathrm{Bu}$ tartışmalar ışığında ortaya çıkan ortak özellikler ve farklılıklar şu şekilde sıralanabilir:

- İki dizi için birinci sezonun sonu yeniden doğuş (dirilme) ile sonlanmıştır. İki mitolojik kahramanın karşısına çıkan insanüstü güç diriltme olmuştur.

- İki dizi için de mitolojik kahraman olarak verdiği savaşta farklı diller temsil edilmiştir.

- İki dizinin geçtiği ve merkezini oluşturan şehirler hikayenin gidişatını etkileyen güçtedir. Atiye için Göbeklitepe ve Nemrut sembol olurken Hakan Muhafız için Ayasofya ön plana çlkarak ve hikayenin can damarını oluşturmaktadır.

- Atiye dizisi daha çok tasavvuf, antropoloji ve astrolojide beslenen olay örgüsüne sahipken, Hakan Muhafiz dizisi tarihten beslenmektedir.

- Atiye dizisinde Şahmeran hikayesi ve diğer hikaye anlatıları Doğu Anadolu Bölgesi'ne ait hikayelerden oluşurken, Hakan Muahfız'ın hikayelerinin odağını İstanbul oluşturmaktadır. Bununla birlikte Atiye dizisinde Süryanice ve Kürtçe temsil edilirken, Hakan Muhafız dizisinde Osmanlıca yer almaktadır.

- Her iki dizide de ortak olan bir diğer nokta görülenin ötesindeki anlamların çözülmesinde şifre olarak kullanılan rakamlar olmuştur. Atiye dizisi için şifre rakamlar Süryanice iken Hakan Muhafız dizisinde Osmanlıcadır.

- Her iki dizide her iki kahramanın çaresizlikleri duvarları tırnakları ile kazıyarak resmedilmiştir.

- Her iki dizide de insan üstü güçlerin belirtisi olarak semboller kullanılmıştır. Atiye dizisinde bu Sirius yıldızı iken, Hakan Muhafız'da sadıkların dövmesi olan anahtar işaretidir.

- Her iki dizide de kahramanların sembol eşyaları bulunmaktadır. Atiye dizisinde bu kolye iken, Hakan Muhafız dizisinde üç kutsal emanet olarak; hançer, tılsımlı gömlek ve yüzüktür.

- İki dizide de kahramanın yolculuğuna edebiyattan beslenen söylemler eşlik etmektedir.

- Her iki dizi içinde kahramanlar aradıkları cevapları bulmak için kutsal mabetlere gitmek zorunda kalmışlar ve buralardaki şifreleri çözebilmek için surelere ayetlere başvurmuşlardır.

Çalışmada incelenen iki Netflix dizisinde kahramanlar ve hikaye anlatılarında Campbell'in (1994) üzerinde durduğu mitin işlevleri çarpıcı bir șekilde öne çıkmaktadır. Bu durum Atiye dizisinde öncelikle toplumsal işlev ile kahramanın kurulu düzenin geçerliliği ve korunması şeklinde hikayede ortaya koyulmuştur. Burada toplumsal Connell (1998)'in toplumsal cinsiyet ilişkilerinin etkileşimi olarak kahramanın gerek kendi hem cinsi olan annesi ile ilişkisi gerekse karşı cins ile ilişkileri çoğunlukla kamusal bir uylaşıma dayanan hegemonik erkeklik ile örtüşmektedir. Kahramanın üzerindeki toplumsal beklentiler ve toplumsal cinsiyetin getirdiği rollerin dinamikliği ile mitin dördüncü işlevi olan bireyin merkezileşmesi ve uyum kazanması da yine Atiye dizisinde kahramanın kendi yaşamına 
ilişkin duyguları ile toplumsal cinsiyet rolünün ona dayattıkları arasındaki çelişkilerde sıkışmışlık söz konusudur. Atiye dizisinde kahraman için kırılma noktası olan gücünü keşfetmesi ise mitin ilk işlevlerinden mistik yönelim yani itaat, huşu ve uyum ile nihai gizemi kabulleniş şeklinde açıkça gözler önüne serilmektedir. Burada yine toplumsal cinsiyet rolleri açısından erkekliğin kültür kadınlığın doğa ile ifade edilişinden yola çıkarak doğanın uyumu ve ikinci işlev olan kozmolojik evren imgesi net bir şekilde anlatı da ortaya konmuştur.

Öte yandan bu durum Hakan Muhafız dizisi için farklı bir süreçte ilerlemiştir. İlk olarak mistik yönelim ön planda olmamakla birlikte birinci öncelik erkeklik algısı ile birlikte güç ve iktidarın temsili şekilde ortaya konmuştur. Kahraman bununla birlikte kurulu düzenin geçerliliği ve korunmasına mutlak sadakatle bağlı iken hegemonik olarak gücün merkezileşmesi de kaçınılmazdır. Huşu itaat gibi mistik yönelimin erkek kahraman için sadece merkezi gücü daha etkin kullanmakta araç olarak ortaya konulması ve mutlak olmayışı kozmolojik yönelim açısından da eksiklikler ortaya koymuştur. Dolayısıyla erkek kahraman için toplumsal cinsiyet rollerinin geleneksel formalarının dayatmaları ve hakim ideolojinin devamlılığı için ön koşuldur.

Her iki dizi içinde toplumsal, tarihsel, kültürel ve psikolojik kurgulamaların varlığından söz etmek mümkündür. Bunun yanı sıra, tarih ve din anlatılarından beslenen her iki dizinin olay örgüsünde ilkel mitlerin özelliklerinden olan kökenleri tanıma ve mitsel kökenli gelenekler anlatılan öyküler olmaktan çok yaşayan bir gerçeklik şeklindedir. Burada gerçeklik her iki dizi içinde sürekli etkileyen canlı bir durumdur ve inanmışlıkla birlikte yazgının ayrılmaz bir parçası ve kabulleniștir.

Bütün bu bilgiler ışığında çalışmada mitolojik anlatıların diziler aracılığıyla farklı toplumsal roller açısından ortaya konulması hem göstergebilimsel hem de söylem analizi yöntemleriyle incelenmiştir. Bununla birlikte ilerleyen çalışmaların söz konusu dizileri ideolojik söylem açısından okuması literatüre anlamlı veriler koyacak önemdedir.

\section{Kaynakça}

Armstrong, K. (2006). Mitlerin kısa tarihi. İstanbul: Merkez Kitapları.

Arsan , E., Ünalan , E., \& Türkoğlu , S. (2009). Cinsiyetçilik ve medya: 'Güzin Abla' köşesinde yeniden üretilen ataerkil cins kimlikleri. Cogito, Feminizm(58), 385402.

Assmann, J. (2015). Exodus and memory. (T. E. Levy, T. Schneider, \& H. C. William , Eds.) USA: Springer.

Bolle, K. W. (2002). Myth. In J. Lindsay, \& G. Thomson , Encyclopedia of religion. New York: Macmillian.

Bulmer, M. (1984). The Chicago School of sociology: Institutionalization, diversity, and the rise of sociological research. Chicago: University of Chicago Press.

Campbell , J. (1994). Yaratıcı mitoloji. Ankara: İmge Yayınları.

Cemal, M. (1996). Eşitlikçi toplumlar: Sömürüsüz bir gelecek için antropolojik inceleme (Vol. ). İstanbul: Belge Yayınları.

Deegan, M. J. (2001). Chicago school of ethnography. In A. I, C. P, D. A, L. S, \& Lof J, The Handbook of Ethnography. London: Sage.

Direk, Z. (2009). Simone De Beauvoir: Abjeksiyon ve eros etiği. Cogito, 58, 11-39. 
Eliade, M. (1993). Mitlerin özellikleri. İstanbul: Simavi Yayınları.

Güzel, E. (2014). Toplumsal cinsiyete dayalı ayrımcılık ve medyanın rolü. Global Media Journal: Turkish Edition, 4(8), 185-199.

Keskintaş, 0. (2013). Anlatıcı, zaman, mekân ve mistik deneyim açısından mitler ve iktidar ilişkisinin incelenmesi. Anemon Muş Alparslan Üniversitesi Sosyal Bilimler Dergisi, 4(1), 125-147.

Koç, T. (2012). Din dili. İstanbul:: İz Yayıncılık.

Malinowski, B. (2000). Büyü, bilim ve din. İstanbul: Kabalacı Yayınevi.

Mead, G. H. (1992). Mind, self \& society from the standpoint of a social behaviorist. Chicago: University of Chicago Press.

O’Reilley, K. (2009). Key concepts in ethnography. Londra: Sage.

Tökel, D. (2000). Divan şiirinde mitolojik unsurlar: Şahıslar mitolojisi. Ankara: Akçă̆ Yayınları.

Tekin, S. (2010). Etik ve insani müdahale: Söylem, mitler ve gerçekler. Konya: Doktora Tezi, Selçuk Üniversitesi.

Williams, R. (2005). Anahtar sözcükler. İstanbul: İletişim Yayınları. 


\title{
Symbolic Interaction in Netflix Turkish Series and Handling of Heroes in Terms of Gender: Comparison of Atiye and Hakan Muhafiz Series
}

\author{
Dilan Çiftçi (Assoc. Prof. Dr.)
}

\section{Extended Abstract}

Myths, legends, and folk tales have important roles in making sense of the lives of people and societies. As in the Western world, it is possible to find important literature sources on this subject. In this study, it is aimed to make readings based on the basic knowledge of the literature in question, how legends and myths find their place in modern society with their functions. Myths and legends contribute to forming the belief worlds of the societies to which they belong. For this reason, they ensure that societies' cultural as well as national codes are formed. As much as possible, you can find that they are effective in preserving, adapting, and applying social values. Starting from the first periods of history, in today's modern life, humans needed time to approach the sacred and supernatural. Today, especially myths appear in different disguises in radio, television, or cinema. On the other hand, it shows itself in rituals or festivals with different religious or cultural content.

In this context, this concept debates in the historical flow have been studied to be examined basically. Unlike other narrative types, its social functions in general and how it reflects on the modern world has been revealed. Netflix's Atiye and Hakan Guard series were examined as case studies. Therefore, this main purpose is to explain how myths make sense of the lives of people on screen. To put it differently how circulation through popular TV series, is a reading of new myths and legends through series with the representation. In this context, by answering the similarities and differences of the legends in the aforementioned 2 (two) series, it is to reveal that myths and legends have many sociological functions and, as in the past, even if they have different perspectives and continue their validity.

Some researchers say that the people that emerged in primitive societies created traditional folk stories in which they embody ideas and beliefs by constructing their history and heroes with collective consciousness (Tökel, 2000, s. 57). The concept of mythology, which is formed as a result of the combination of the words myth and logia, which means word, tale, legend, or discourse, also comes from the word mythos, which means the word is spoken and the word heard in Greek (Bolle, 2002, s. 13). Karen Armstrong states that myth can also be seen as a word or art, indicating the timelessness in the process of human existence in ancient times, and states that it is a kind of art that provides access to the true essence of the events experienced (Armstrong, 2006, s. 11). Myths cannot always be regarded as abstract realities of symbolic expressions. The main reason for attracting societies is the effects they create rather than the accuracy of the information they contain. Hence, myth and history, or tale and myth narratives, feed off each other in the context of the historical past.

The narratives of mythological stories, legends, and heroes are mostly revealed with a male-dominated approach. The serials Atiye and Hakan Guard, which have been very popular recently, provide important data in terms of handling different perspectives from 
two different gender aspects. From this point of view, it would be an appropriate result to say that the existing gender understanding in this study has continued its existence both in the past and in new productions. However, the focus and reference points of these two series differ in terms of mythological narratives. While the power of the male hero was more depicted and associated with the stories of the Ottomans and sultans with his works, religious and spiritual doctrines for the power of the female hero were in question. The prominent places and places in the two series are in the form of historical artifacts of the region where they were shot. From this point of view, the two series made important contributions to symbolizing some phenomena in terms of symbolism. Despite the fantastic fiction and plot, the frequent use of advice about life and stories and discourses that cause life to questions in both series reveals important ideologically important data. The two series maintain their importance in terms of the mythological heroes coming out of historical narratives and fairy tales and re-circulating in daily life with popular TV series. The general findings of the study can be listed as follows:

- For two series, the end of the first season ended with a rebirth (resurrection). The superhuman power that confronts the two mythological heroes has been a resurrection.

- Different languages were represented in the battle s/he fought as a mythological hero for both series.

- The cities that the two series take place and form the center are powerful in affecting the course of the story. While Göbeklitepe and Nemrut are symbols for Atiye, Hagia Sophia stands out and constitutes the lifeblood of the story for the Hakan Guard.

- While the Atiye series has a plot nourished in mysticism, anthropology, and astrology, the series Hakan Guardian is fed from history.

- While the story of Sahmeran and other story narratives in the Atiye series consists of stories from the Eastern Anatolia Region, Istanbul is the focus of Hakan Muahfız's stories. However, while Syriac and Kurdish are represented in the TV series Atiye, Ottoman Turkish is included in the series Hakan Guard.

- Symbols are used as signs of superhuman powers in both series. While this is the star of Sirius in the series Atiye, it is the key sign that is the tattoo of the faithful in the Hakan Guard.

- Both series have symbol items for the heroes. While this necklace is in the series Atiye, as three sacred relics in the Hakan Guard series; the dagger is a talismanic shirt and ring.

Keywords: Communication, Myth, Mythological Hero, Superhuman Powers, Legendary Objects, Gender.

Bu makale intihal tespit yazılımlarıyla taranmıştır. Intihal tespit edilmemiştir.

This article has been scanned by plagiarism detection softwares. No plagiarism detected.

Bu çalışmada "Yükseköğretim Kurumları Bilimsel Araştırma ve Yayın Etiği Yönergesi” kapsamında uyulması belirtilen kurallara uyulmuştur.

In this study, the rules stated in the "Higher Education Institutions Scientific Research and Publication Ethics Directive" were followed. 